\title{
El arquitecto académico a finales del siglo XVIII
}

\author{
José Enrique García Melero*
}

\begin{abstract}
RESUMEN
ABSTRACT

Estudio sobre el arquitecto español In this paper it is studied the spanish durante los años finales del siglo XVII: su formación en la Academia madrileña, libros empleados en ella, las pensiones en Roma y los examenes de los distintos profesionales de la arquitectura. También se analizan la actuación de los profesores, de los académicos de mérito, de los arquitectos de provincias y de los itinerantes en la llamada Comisión de Arquitectura, que desde 1786 censuraba los proyectos de obras públicas españolas importantes. Se estudian una serie de reales órdenes sobre las distintas profesiones de la arquitectura y los planes de estudios de 1799, en especial el informe de Silvestre

Pérez, y de 1806. El artículo concluye con una sintesis sobre la situación de las distintas profesiones de la arquitectura a finales de la Guerra de la Independencia al llegar al trono el Rey Fernando VII. architect in the last years of the eighteenth century: his education in the Madrilenian Academy, the books used, the grants in Rome and the exams that the different professionals had to pass. It is also analyzed the role played by the teachers, the academicians of merit, the county architects and the itinerant ones in the so called Commission of Architecture, which censured the proyects of some important spanish public works since 1786. Besides, it is studied some royal orders related to different careers of the architecture and the syllabus in 1799, specially the Silvestre Pérez's report, and in 1806. To end it is made a brief exposition on the different careers of the architecture since the end of the Independence War to the arrival of Fernando VII to the royal throne.
\end{abstract}

- Departamento de Historia del Arte. UNED. 
La Academia madrileña, a pesar de su plurifuncionalismo, tuvo como principal finalidad la formación individual y también, sobre todo, colectiva del artista tanto en la teoría como en la práctica del arte. Sin embargo, desde un principio se quiso siempre destacar, aunque se pretendía un cierto equilibrio, ese componente conceptual logrado en el estudio meditado de las fuentes literarias artísticas y de las publicaciones del momento, especialmente extranjeras. Era una forma de diferenciar la actividad académica intelectual y liberal -vinculada directamente con el Rey y a través suya con un Estado borbónico moderno, ilustrado, centralista y uniforme- de la gremial, en la que se quiso ver una diversidad y un exclusivo componente pragmático desprovisto de toda consciente reflexión teórica, deficiencia vinculante con el aprendizaje artesanal. Pero, además, se deseó significar por el empleo como norma de un lenguaje universal, basado en reglas fijas e inmutable, e histórico, de una constante cíclica artística atemporal y en eterno retorno, el clasicismo. Su utilización también distinguía al artista académico del practicante gremial, anclado en el uso abusivo de formas decorativas excesivas, especialmente costosas. Por ello, y desde una concepción enciclopédica, la Academia buscará la economía de las fábricas a través de ese clasicismo y querrá que el artista sepa distinguir lo necesario de lo que era superfluo a todas luces. La concepción teórica, el "ensueño clásico", no estaba reñida, así pues, con un claro componente pragmático y funcional en su realización.

Este carácter docente de la Academia promovió la preocupación de sus distintos integrantes -estamentalmente configurados en consiliarios aristocráticos, políticos y literatos, y artistas facultativos en una lucha continua por conseguir el poder-por mejorar siempre el sistema pedagógico dentro de un esquema constante y vertebral. Se quiso controlar de una forma racionalmente metódica tanto la formación del artista como la práctica cotidiana de las distintas profesiones dentro del código clásico y en la economía, que de la unidad deseada pasó casi imperceptiblemente a la diversidad dialectal, origen de posteriores libertades interpretativas heterodoxas. De aqui la periodicidad de las reformas más o menos epidérmicas o endémicas dentro de ortodoxas reglas inmutables por medio de proyectos de nuevos planes de estudios, unos llevados a la práctica y otros dejados sobre el papel con cierta indolencia por realizarlos.

De entre los distintos géneros artístico la arquitectura se fue diferenciando con el paso del tiempo de las artes figurativas por considerarse como la más necesaria para la sociedad por su incidencia en la vivencia 
cotidiana del hombre a través de su casa y de la ciudad, y debido a ser la imagen más visible del arte. Además, se consideraba que en la formación del arquitecto había un componente mucho más teórico que en la del resto de los artistas, elemento conceptual que no estaba en discordancia con la necesidades vitales del hombre. La arquitectura aparecía como el arte más imprescindible de todos.

\section{LA IMAGEN TÓPICA DEL ARQUITECTO ACADÉMICO}

El arquitecto académico ofrece popularmente en nuestros días la tópica y hasta poco atractiva imagen para muchos de un artista siempre sometido a reglas y obligaciones, a doctrina y formalidades. Se le considera, así, como un clasicista convencido, racional, metódico, frío burócrata y funcionalista, más teórico que práctico, sin apenas ninguna capacidad para salirse de esa normativa convencional a veces asfixiante y para crear proyectos ambiciosos novedosamente libres e imaginativos. La Academia, el centro promotor, aparece en paralelo casi como una especie de tribunal inquisitorial, que ataba a sus arquitectos, primero sometiéndoles desde una temprana edad a un rígido aprendizaje dentro de esos principios clásicos por medio de continuas pruebas y examenes, y después controlando doctrinalmente todos sus proyectos a través de una comisión integrada por los profesores colegiados más ortodoxos con el sistema. Su imagen resulta desde esta perspectiva bastante poco agraciada al ser comparada con la representación mucho más agradable, también común y tópica, ofrecida por los llamados "artistas rebeldes» del romanticismo, en busca continua de una libertad siempre codiciada y entre sueños tal vez inexistente, o con los "osados y bohemios" de las primeras vanguardias, que rompen con las últimas reglas y parecen poner "patas arribas» todos los dictados estéticos.

Sin embargo, no se puede olvidar nunca, al margen de tales clichés populares - que simplemente son tópicos de análisis preconcebidos-, el importante papel desempeñado por ellos en la modernización de la ciudad y de la arquitectura españolas durante la llustración. Se integraron en los movimientos artísticos del momento en Europa al asumir un lenguaje universal y secular, que, no obstante, hicieron derivar por diversos caminos. Tampoco se debe silenciar el carácter de "vanguardia" que el academicismo tuvo en su época al romper con el sistema gremial, que regía secularmente en las artes plásticas, ni su condición de auténtico laboratorio científico de cuantas alternativas se tomaron después. No en vano la segunda mitad del siglo XVIII fue un ir y venir 
continuo de lenguajes artísticos, que llegaron, se experimentaron y pasaron casi vertiginosamente, siendo de este modo el precedente, la introducción, y el resumen, la sintesis, de lo que ocurriría en la siguiente centuria.

El artista académico del siglo dieciocho, el llamado "neoclásico», fue el primer gran "romántico» obsesionado por la Historia, si se establece en esta obsesión una de las características del romanticismo tal y como la historiografía suele insistir. Al tratar de justificar su credo en el clasicismo buscó su huella en el devenir del tiempo pasado, de forma especial en la Antigüedad grecorromana y en el Renacimiento, y halló otros períodos atractivos no ortodoxos con su idea preconcebida. Percibió la pluralidad de opciones posibles a seguir y acabó admitiendo, además, que ese clasicismo no era único e inequívoco en la Historia, sino múltiple y hasta difuso, permitiendo recreaciones y adaptaciones a las necesidades de cada momento. Pero, además, el artista académico fue un viajero incansable en busca de las ruinas de la Antigüedad, que muchas veces reprodujo evocativamente y en otras recreó. En tal recreación o trató de hallar la verosimilitud o se dejó llevar por su imaginación, y hasta por el pintoresquismo.

El arquitecto académico español de finales de la llustración, que usó del dibujo como lenguaje específico del arte, se vinculó, no sin polémicas, con ciencias como las matemáticas, la física y la química para actualizarse y perfeccionar su actividad. Evolucionaría, asi, hacia una encrucijada propia donde arte, ciencia y técnica se encuentran, y al final se especializaria. Se dividió en varias profesiones al percibir que, si la arquitectura tenia un indudable componente artístico, también necesitaba de la ciencia y de la técnica.

\section{LA FORMACIÓN DEL ARQUITECTO EN LA ACADEMIA}

El artista debía poseer una formación completa con un equilibrio adecuado entre un aprendizaje teórico y otro práctico, sin que ninguno de estos dos componentes didácticos predominase el uno sobre el otro. Sin embargo, la Academia esgrimió la importancia que en ella se daba a la parte conceptual como arma didáctica y también dialéctica en su pugna contra los practicantes gremiales de las Bellas Artes, ignorantes -o asi se pensaba o se quería razonar - en gran parte de esa capacidad teórica. Las distintas profesiones relacionadas con la arquitectura dependian del mayor o menor conocimiento de la tratadística, y, por lo tanto, de su mayor o menor posesión de conceptos. 
No resulta extraño, por lo tanto, que Juan de Villanueva en sus manuscritos de 1781 sobre el "nuevo arreglamiento", que se quería establecer para la aprobación de las distintas profesiones de la arquitectura, estableciera un sistema jerárquico piramidal, muy del agrado de este instituto '. Tal configuración estamental, tan propia de la sociedad de la época, pero con cierta posibilidad de acceso de unas profesiones a otras a los mejores individuos de cada clase, se regía obviamente por el grado de capacidad teórica. No obstante, siempre, aún en los títulos más elevados, el arquitecto del Rey requería también la posesión de una práctica totalmente necesaria. En la base de esta pirámide de la arquitectura figuraban los oficiales de albañilería, canteros y carpinteros, después los maestros de obras, sobre los que destacaban los arquitectos y, por último, los académicos de arquitectura. Sobre ellos figuraban los tenientes y directores de la Academia, encargados de la docencia y, después, de la censura de los proyectos de obras públicas de consideración, y, por último, los arquitectos del Rey, quienes no tenían que rendir cuentas a este centro de su actividad, aunque estuviesen integrados en él ${ }^{2}$.

La Academia, no obstante, asumió el doble papel de centro de formación de artistas y de artesanos por disposición de los políticos reformistas como el Conde de Floridablanca entre 1777 y 1791. La llustración intentó fomentar la enseñanza de aquellas artes útiles imprescindibles para el desarrollo económico del Reino. Se trataba de aumentar su capacidad productiva por medio de la educación. Esta doble misión pedagógica del instituto produjo la falta de definición en sus objetivos principales, pues asumiria al mismo tiempo los papeles de Academia y de Escuela, siendo por ello cuestionado por Juan de Villanueva en su informe de 1792, quien deseaba un retorno a los orígenes del instituto ${ }^{3}$.

VILI ANUEVA, J. DF, "Sentir sobre el nuevo arreglamiento, que se premedita establecer para la aprobación de Maestros de obras y Arquitectos, y la recepción de Académicos". Madrid, 23 de abril de 1781. También: “Extracto de un papel escrito por el Arquitecto D. Juan de Villanueva, en orden a la distinción de Profesores de Arquitectura y al examen de ellos, según sus clases, en la Academia". (S.I.: Madrid, s.f.: 1781). Archivo de la Real Academia de Bellas Artes de San Fernando, Madrid (a partir de ahora: AASF): leg:: 17-3/1.

Sobre estos manuscritos de Juan de Villanueva y de otros arquitectos, como Ventura Rodríguez, Miguel Fernández, Pedro Arnal y José Moreno, vid.: Garcia MELERO, J. E., “El debate académico sobre los exámenes para las distintas profesiones de la Arquitectura (1781-1783). (EI arquitecto según Juan de Villanueva)". Escoacio. Tiempo y Forma, serie VII, $H^{a}$ del Arte, t. VI. Madrid, UNED. 1993, págs. 325-378.

Villanueva, J. DE, “Informe sobre los estudios en la Academia». Madrid, 20 de julio de 1790. AASF: 18-1/1. Su estudio en GARCIA MELERO, J. E., "Los orígenes académicos del romanticismo histórico español: Malestar y crisis en torno a 1792". Espacio, tiempo y forma. serie VII, t. V. Madrid, UNED, 1992, págs. 211-262. 
La enseñanza del dibujo fue el nexo en la formación de artistas y de artesanos, y también entre los distintos géneros artísticos. Éstos solían aprender en el taller del maestro y también en las Reales Sociedades Económicas de Amigos del País. El Conde de Campomanes, fiscal del Consejo de Castilla, trató de fomentar en 1774 la educación popular de los artesanos para mejorar la producción del país ${ }^{4}$. Una alternativa fue la creación de las Escuelas de Dibujo en España, pues no se deseaba que las Academias proliferaran por el Reino, sobre todo durante el gobierno del Conde de Floridablanca como ministro de Estado con Carlos III (lám. 1) ${ }^{5}$. Si las artes útiles debían promoverse, también era preciso restringir el incremento innecesario de artistas, y centralizar su formación en unos pocos institutos. Así, la segunda Academia, que se fundó, sería la de San Carlos de Valencia en 1768, cuyos estatutos pulieron y perfeccionaron los de la madrileña. A ella siguieron las de San Carlos de México (1783) y de San Luis de Zaragoza (1792). Si aquélla se originó en la Escuela de Grabado de Nueva España (1781), dirigida por Jerónimo Antonio Gil ${ }^{6}$, ésta tuvo como inicio la Escuela de Dibujo patrocinada por la Real Sociedad Aragonesa de Amigos del País. Ya en 1802 se creó la de Valladolid. Hasta el año 1849 la Escuela Gratuita de Dibujo de la Llotja o Lonja de la Junta de Comercio de Barcelona (1775) no se convirtió en Real Academia de Bellas Artes, aunque en la práctica funcionase como tal, pues llegó a contar desde 1817 con una importante clase de arquitectura, dirigida por Antoni Celles. Todas ellas se basaron en el sistema jurídico y pedagógico de la Real Academia de Bellas Artes de San Fernando de Madrid, que siempre sirvió de referencia y de órgano académico superior entre ellas. Hubo Escuelas de Dibujo, como la de Granada, que desde sus mismos inicios pretendió transformarse en Academia ?

La formación del pintor y del escultor pasaba por el aprendizaje a través de las diversas salas de la Academia madrileña en tres etapas con-

Rodriguez Campomanes, P., Discurso sobre el fomento de la industria popular. Madrid Antonio Sancha, 1762, y Discurso sobre la educación popular de los artesanos y su fomento. Madrid, Antonio Sancha, 1775.

5 BEDAt, C.: La Real Academia de Bellas Artes de San Fernando (1744-1808). Madrid. Fundación Universitaria Española - Real Academia de Bellas Artes de San Fernando, 1989, pág. 408.

Garcia Melero, J. E., "Nexos e influencias entre las Reales Academias de Bellas Artes de San Fernando y de San Carlos de México". En el libro Influencias artísticas entre España y América. Madrid, Ed. Mapłre América, 1992, págs. 259-360..

Garcia Melero, J. E., "Retazos de la Escuela de Dibujo de Granada en la Real Academia de Bellas Artes de San Fernando (1777-1816)". En el libro La imagen romántica del legado Andalusí. Granada, Lunwerg Editores, 1995, págs. 125-138 


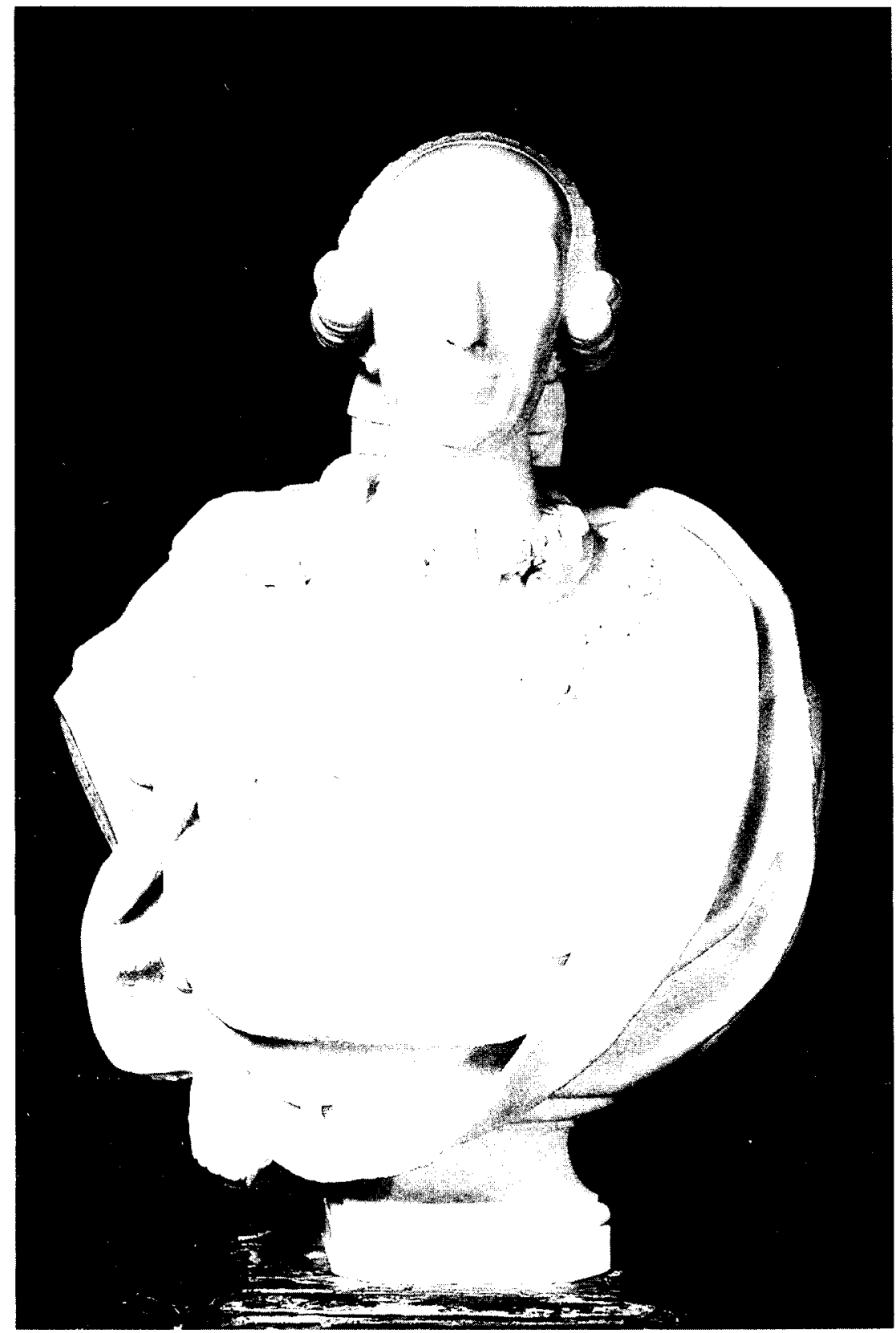

Lám. I: Busto de Carlos III (1764) por Juan Pascual de Mena. Mármol de Carrara. Museo de la Real Academia de Bellas Artes de San Fernando. 
secutivas: de principios, de yeso y de modelo vivo ${ }^{8}$. La primera tenía como objetivo principal el dibujo del cuerpo humano, y era compartida por artistas y artesanos. Después de un examen el discipulo se incorporaba a la de yeso, mientras que los futuros arquitectos pasaban a la de matemáticas. Inicialmente se copiaron modelos de yeso de escultores barrocos, pero más tarde se tomaron como ejemplos a seguir los vaciados de esculturas grecorromanas, muchos de ellos encargados en Roma. En la sala del natural posaban tres modelos por las noches, alternándose semanalmente y haciéndolos juntos la última de cada mes, con la finalidad de que los discípulos dibujaran composiciones en grupo. La copia de telas tuvo gran importancia, mientras que el colorido se aprendía en el taller de un maestro.

El aprendizaje de la arquitectura resultaba bastante más complejo. Dado el componente práctico de esta disciplina y su repercusión en la sociedad a través de la ciudad, su utilidad y necesidad, fue objeto de una atención diferente y hasta preferente. Su enseñanza se separó de la pintura y escultura, impartiéndose en salas distintas. Su base inicial se hallaba en el estudio preliminar de la geometría práctica. Los planes de estudios fueron siempre objeto de debates internos. Hay que destacar la polémica de 1792-1793 entre los arquitectos y el matemático Antonio de Varas, quien deseaba dar al arquitecto una formación más científica basada en el aprendizaje de las matemáticas, la física y la química frente al predominio excesivo de la enseñanza del dibujo, nexo entre las artes y lenguaje peculiar del artista ${ }^{9}$. Por ello el futuro arquitecto debía aprender la perspectiva, la geometría, las matemáticas... En 1799 se propuso un plan de estudios más científico con estudios de matemáticas aplicadas a la arquitectura, geometría, física experimental y en especial óptica, mecánica e hidráulica, perspectiva..., pero también más humanístico con el aprendizaje de la gramática castellana, de historia de las Bellas Artes y de nociones de geografía ${ }^{10}$. Se consideraba a todas estas materias como ciencias auxiliares de la arquitectura.

Ya hacia 1757 el Conde de Aranda había redactado un dictamen sobre los estudios de la arquitectura, dividiendo su enseñanza por medio de los

\footnotetext{
\& ÚBeda de los Cobos, A. Pintura, mentalidad e ideología en la Real Academia de Bellas Artes de San Fernando. 1741-1800. Madrid, Editorial de la Universidad Complutense, 1988. Vid. págs. 471-478.

Garcia Melero, J. E., "Los origenes académicos del romanticismo...", pág. 235-246. El manuscrito de Varas del 9 de octubre de 1792 en AASF: leg.: 18-20/1

15 AASF: legs.: 18/4-1 y 18/8-1.
} 
principios clásicos de firmeza, hermosura y comodidad ${ }^{11}$. En la primera parte se debía estudiar aritmética, geometría, materiales y sus usos, calidades de los terrenos, modo de fábricas, carpintería, estacadas y construcciones de máquinas. La hermosura residia en el conocimiento de los cinco géneros de edificios antiguos y de los cinco ordenes, de la perspectiva y de la óptica. La comodidad obligaba a saber la situación de las construcciones, su disposición, fortificación, templos, plazas, demás edificios públicos y casas particulares. Su idea era que los profesores arquitectos se dividieran los temas propuestos para redactar un tratado, que sirviese de libro de texto en la Academia, empresa que siempre fracasó.

Hubo una serie de materias, que se fueron imponiendo poco a poco en este instituto, que eran sobre todo necesarias para los discípulos de arquitectura. Así, en 1766 y por recomendación del pintor Mengs se impuso el estudio de la perspectiva, siendo nombrado Alejandro González Velázquez primer profesor de esta materia interdisciplinar, sucediéndole los arquitectos Miguel Fernández y Guillermo Casanova ${ }^{12}$. La perspectiva fue enseñada a finales del siglo, antes que los estudios propios de la arquitectura.

La junta ordinaria del 8 de marzo de 1767 acordó dotar una cátedra de matemáticas; pero un año después, en septiembre de 1768 , se crearon dos directores de esta disciplina: Benito Bails y Francisco Subirás. Aquél se encargó de la redacción de un curso de matemáticas para los discípulos de arquitectura, mientras que éste renunció a tal empleo en agosto de 1769, al hallarse en Barcelona ocupado en el arreglo de los estudios del colegio de Cordellas. No sería sustituido hasta marzo de 1777 por José Moreno, hijo del conserje de la Academia y que habia ayudado a Bails como amanuense.

En la formación colectiva académica para el ejercicio de la arquitectura tuvo, así pues, obviamente mucha importancia la misma configuración jerárquica de la profesión, que dependía tanto de las relaciones existentes entre los conocimientos teóricos y los prácticos, como de su grado de especialización. Por ello la Academia cuidó mlicho de establecer distinciones entre los diferentes profesionales en función de los conocimientos adquiridos durante el aprendizaje, de los cuales se daba cuenta por los resultados obtenidos en los exámenes. Interesaba definir perfectamente las dife-

"Conde de ARANDA, "Dictamen del Consiliario... sobre el Curso de Arquitectura". (S.f.: 1757?). AASF: leg.: 18/9-1.

Quintana Martinez, A., La Arquitectura y los arquitectos en la Real Academia de Bellas Artes de San Fernando (1744-1774). Madrid, Xarait, 1983. Vid. págs. 66-67. 
rencias existentes entre los académicos, los arquitectos y los maestros de obras. De aquí que en la última década del siglo XVIII se dictaran una serie de medidas para estructurar perfectamente el campo de actuación de cada grado y las pruebas que debian de realizar para alcanzarlo. A algunas de ellas me referiré a continuación.

Así, en 1792 Pedro de Silva criticó la distinción existente entre el arquitecto y el maestro de obras ${ }^{13}$. Este título sería suprimido por una disposición del año $1796^{14}$. Se decidió que a partir de entonces tan sólo se expedirían dos títulos: el de maestro arquitecto y el de académico de mérito. El primero tendría un carácter de aprobación para el desempeño de este arte, mientras que el segundo lo poseía de incorporación a la Academia. El 23 de mayo de 1800 se reguló por real orden el acceso al grado de académico de mérito por medio de una disertación o discurso sobre algún punto de su arte antes sorteado, que el aspirante debía enviar por escrito ${ }^{15}$. El sistema no era nuevo. Ya se había debatido mucho sobre el particular, aunque esa real orden fuese la consecuencia directa del debate sobre el nuevo plan de estudios de 1799.

Hubo durante el último cuarto del siglo XVIII una serie de disposiciones de interés para el ejercicio de la arquitectura por parte de los distintos profesionales de esta bella arte, que aqui expondré con cierta brevedad, destacando las más importantes. En el fondo, se trataba de establecer con elias la defensa profesional del arquitecto formado en la Academia, o aprobado por ella, frente al maestro gremial ${ }^{16}$.

Así, en 1787 se dispuso que los arquitectos o maestros mayores de las capitales y cabildos eclesiásticos principales del Reino debian ser los académicos de mérito de San Fernando o de San Carlos para el reino de Valencia. En el caso de que hubiese una vacante, se debería avisar a dichas Academias, indicando el sueldo asignado y los sujetos, que consideraban apropiados para ocuparla, antes de que tomasen posesión del puesto ${ }^{17}$. Ambos institutos comprobarían entonces, si estaban en posesión de ese grado y si había o no reparo alguno, que impidiera su nombramiento. Esta disposición era una consecuencia de la negligencia, que se habia

Silva, P. de, "Reflexiones sobre los estudios de Arquitectura de la Real Academia de San Fernando". 6 de noviembre de 1792. AASF: leg.: 18-1/1

Real orden del 18 de noviembre de 1796.

Real orden de 27 de mayo de 1800. AASF: leg.: 17/5/1. El tema se habia estudiado en la junta ordinaria del 4 de mayo de 1800. AASF: leg.: $3 / 86$, fol. 138

Para el estudio del arquitecto cel Barroco es importante: Garcia MORALES, Ma. V., "La figura del arquitecto en el siglo XVI'». Madrid, UNED, 1991

Real orden circular expedida el 28 de febrero de 1787 en El Pardo. AASF: leg. 28-1/1.. 
advertido, a la hora de cumplir lo que el Rey había mandado en los Estatutos de ambos centros sobre la aprobación de estos cuerpos. Se basaba en el artículo 33 de los Estatutos de la Academia madrileña de 1757. Además, quedaban literalmente abolidos desde entonces los privilegios que "contra el verdadero crédito de la Nación y decoro de las Nobles Artes conservan algunos pueblos de poder dar Títulos de Arquitectos y de Maestros de Obras arbitrariamente a sujetos por lo regular incapaces". Por último, en esta disposición de 1787 se recordaba la orden del Rey a la Academia de Valencia del 24 de junio de 1784 y la circular dirigida a los Obispos y Prelados del Reino del 25 de noviembre de 1777. Por ella se mandaba que el diseño de los retablos y demás obras de templos debian presentarse a una de las dos Academias para su aprobación. Se refería, asimismo, que de igual forma se habría de practicar con cualquier edificio público, que se intentase construir de nuevo o reparar en parte principal.

En 1798 se recordó la orden circular de 25 de noviembre de 1777, por la cual todos los Ayuntamientos, Cuerpos, Magistrados y personas a quienes competiese, deberían dirigir, antes de al Consejo, los proyectos, planos y dibujos de obras de Arquitectura a la Academia para su examen y aprobación, o enmienda, en el caso de ser necesaria. Se debian explicar convenientemente por escrito los dibujos, planos, alzados y cortes de la fábrica ideados. Los profesores de este instituto los examinarían con toda atención, con brevedad y de forma gratuita. Se advertirían su mérito o los errores cometidos, dándose la certificación correspondiente por el secretario de la Academia ${ }^{18}$. En este mismo aspecto se incidió en 1801. Hay que destacar aquí que tal control sobre la arquitectura, habido desde 1777 y pretendida ya a partir de 1768 , se extendió en 1808 a la pintura y a la escultura. Así, se debían presentar a esta institución los diseños de pinturas o estatuas, que hubieran de colocarse o fijarse en sitios públicos y templos, a expensas de los caudales también públicos o de comunidades o de otros cuerpos ${ }^{19}$.

\section{APROXIMACIÓN A LA BIBLIOTECA IDEAL DEL ARQUITECTO ACADÉMICO}

El conocimiento de la tratadística era muy importante tanto en la formación como en la práctica profesional de los artistas académicos ${ }^{20}$. De

Real orden circular del 20 de diciembre de 1798.

Real orden del 11 de enero de 1808.

Las ideas estéticas, la teoría del arte, a través de los libros ha sido estudiadas por: Henares Cuéllar, I., "La teoría de las Artes plásticas en España en la segunda mitad del siglo xVII'’. Granada, Departamento de Historia del Arte, 1977. 
ahí que la Academia se preocupara de formar una biblioteca con los principales libros sobre las Bellas Artes españoles y extranjeros, de reimprimir los tratados escritos en castellano, de traducir las publicaciones imprescindibles ${ }^{21}$ y de redactar, o intentarlo, sus propias obras ${ }^{22}$. Ya el Conde de Aranda en su dictamen de hacia 1757 se mostró partidario de realizar una breve, pero importante y selectiva, política de traducciones y reediciones de tratados clásicos de arquitectura: las obras de Vitruvio - teniendo presente la edición francesa de Perrault-, Serlio, Scamozzi, Alberti y Palladio —en la consideración de la reimpresión veneciana de 1740En esta misma línea insistió Diego de Villanueva, profesor de arquitectura en la Academia, en su plan de exámenes de arquitectura de 1768 presentado a la junta particular.

La sugerencia de Aranda se cumplió en gran parte a lo largo del último tercio del siglo XVIII; pero la realización de libros propios por parte de los profesores de la Academia resultó en la práctica un fracaso a pesar de los intentos malogrados ${ }^{23}$ (lám. II). Era urgente reeditar "De Architectura" de Vitruvio, arquitecto romano de la época de Augusto, obra tardía de la Antigüedad clásica, ecléctica y sintética de diversas fuentes antiguas. La edición príncipe había aparecido en Roma hacia 1483 o 1486 y la primera traducción española se publicó en 1582, habiendo sido realizada por Miguel de Urrea, un modesto ensamblador, y por el impresor alcalaíno Juan Gracián ${ }^{24}$.

Durante la segunda mitad del sigio de la llustración se publicaron dos ediciones de los diez libros escritos por Vitruvio, que sirvieron de modelos a otras tantas generaciones de arquitectos. En 1761 José de Castañeda, profesor de geometría de la Academia formado en Francia, tradujo el "Compendio de los diez libros de Arquitectura" del francés Claude Perrault ${ }^{25}$. Significa la adopción oficial y pública de un texto resumen del

Es imprescindible para el conocimiento de la tratadistica arquitectónica de la llustración el siguiente capitulo: SAMBRICIO, C., "La arquitectura de la segunda mitad dei siglo xvill y los ideales de la razón". Juan de Villanueva, arquitecto (1739-1811). Madrid, Delegación de Cultura del Ayuntamiento, 1982, págs. 3-31.

BEDAT, C., "La Biblioteca de la Real Academia de Bellas Artes de San Fernando en 1793". Academia, núms. 25 y 26, págs. 5-52. Madrid, segundo semestre de 1967-1968.

23 Obra importante para el estudio de la teoría arquitectónica durante la llustración es: LEON TEllo, F. J. y SANZ SANZ, Ma. V., "Estética y teoria de la arquitectura en los tratados españoles del siglo Xvili’. Madrid, C.S.I.C., 1994

2 Garcia Melero, J. E., "Las ediciones españolas "De Architectura" de Vitruvio". Fragmentos, núms. 8 y 9, págs. 102-131. Madrid, Ministerio de Cultura, 1986.

BÉrChez Gomez, Joaquín: "La difusión de Vitruvio en el marco del neoclasicismo español». Estudio introductorio a la edición facsímil de: PERRAULT, C., "Compendio de los diez libros de Arquitectura”. Traducción de Joseph Castañeda. Murcia, Colegio Oficial de Aparejadores, 1981, págs. IX-XCI. Original en Madrid, en la Imprenta de D. Gabriel Ramirez, 1761. 

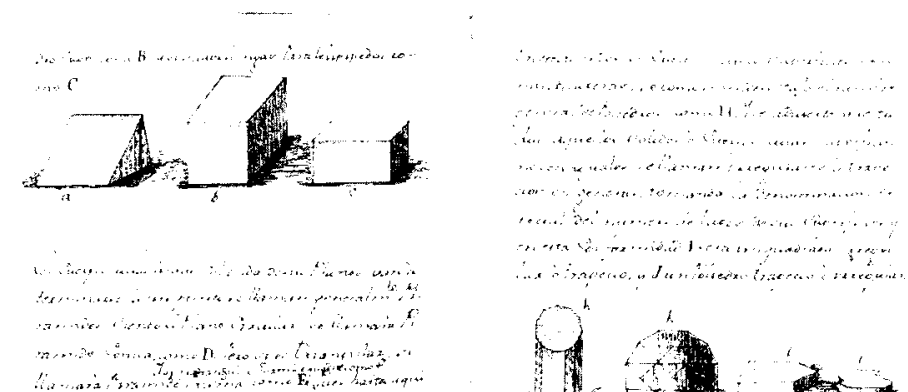

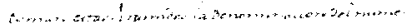

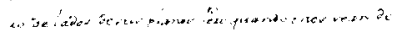

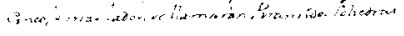

cor 6

1
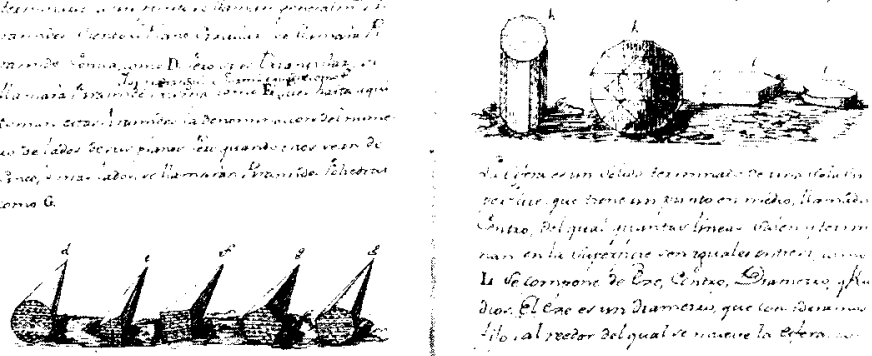

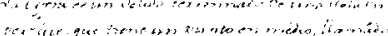

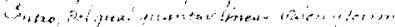

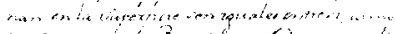

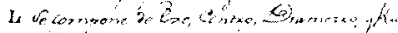

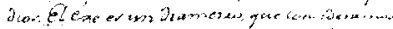

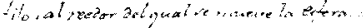

Lám. II: "Tratado de Geometría práctica" de Ventura Rodriguez. Manuscrito fechado en Madrid el 18 de mayo de 1755. AASF: A: 311-32/3.

tratado complejo de Vitruvio por la generación académica de 1715-1726 con finalidad docente. Se había elegido la óptica de un arquitecto francés del barroco clasicista, que habia intervenido en la realización de la fachada del palacio del Louvre. A esa generación pertenecieron Diego de Villanueva, Ventura Rodríguez y José de Hermosilla, quienes desempeñaron un papel importante en la asimilación y penetración del clasicismo durante las décadas de los años cincuenta y sesenta.

La segunda edición de 1787 del tratado de Vitruvio se debe al filólogo y arqueólogo, humanista ilustrado, José Ortiz y Sanz ${ }^{26}$. Parece obedecer a las necesidades de la generación de arquitectos nacidos en los años treinta, como Juan de Villanueva y Pedro Arnal, y a las exigencias de la Comisión de Arquitectura de la Academia madrileña, creada en 1786 para controlar los proyectos de cuantas obras públicas se realizaban en España. La actividad del presbítero valenciano resulta imprescindible para

Rodrigue ? Ruiz, D., «José Ortiz y Sanz: "Atención y Pulso" de un traductor». Estudio introductorio a la edición facsimil de Madrid. Akal, 1987. La edición original en Madrid, Imprenta Real, 1787 
acercarnos a la teoría y a la práctica arquitectónicas españolas del último cuarto del siglo XVIII. A través de sus traducciones puso al alcance de los arquitectos y de la Academia las teorías de Vitruvio, de Milizia (1789), de Palladio (1797) y de Bottari (1804). Con ello no sólo facilitó la penetración del clasicismo y su evolución, sino también de un racionalismo, a veces ecléctico, a veces funcionalista, y hasta, quizás un cierto prerromanticismo arquitectónico. Su labor no se redujo a la tarea filológica, pues fue, además, un comentarista, que en las traducciones introdujo su visión personal $y$, asimismo, un erudito de gran rigor y sabiduria. No obstante, la traducción de 1787 de Vitruvio se publicó en España a destiempo (lám. III). Por estas fechas el concepto de clasicismo estaba pasando de ser univoco a equívoco, poniéndose en entredicho en Europa al arquitecto romano como canon único. Sus teorías y estudios de las proporciones habían sido comparadas por medio de un riguroso método arqueológico con los restos de la Antigüedad. Se percibieron en ellos ciertas incongruencias, deduciéndose la idea de la multiplicidad del fenómeno clásico.

Pero la principal obsesión en estos momentos era la reedición de los tratados renacentistas y manieristas italianos ${ }^{27}$. En 1792 Fausto Martínez de la Torre y José Asensio tradujeron e hicieron las estampas de las "Reglas de los cinco ordenes de arquitectura de Vignola" según Delagardette (lám. IV). De esta forma se introdujo en la Academia la visión pragmática, pero ciertamente subjetiva de Vignola (1507-1573) de los cinco ordenes clásicos, quien por medio de una convencional regla matemática, producto de mediciones contradictorias de los elementos arquitectónicos, estableció una relación general entre el pedestal, la columna y el entablamento. A través de un módulo fijó las proporciones entre el radio de la columna y los distintos componentes de un orden arquitectónico. El tratado de Vignola ya había sido traducido por Diego de Villanueva en 1764; pero hay una serie de diferencias entre ambas versiones. Si éste deseaba recoger su espíritu con fidelidad, queriendo divulgar un sistema representativo del ideal clásico, la traducción de 1792 lo interpreta con aportaciones novedosas, con la idea de reflejar luces y sombras en las estampas.

En esta misma línea por contar con un repertorio completo de tratados del clasicismo se halla la reedición de "Los cuatro libros de Arquitectura" de Palladio ${ }^{28}$. Hay que destacar aquí el interés que el palladianismo tuvo

Garcia Melfro, J. E., "Documentos y libros". En el libro "Renovación, crisis, continuismo. La Real Academia de San Fernando en 1792. Madrid, Real Academia de Bellas Artes de San Fernando. 1992, págs. 99-158.

28 WIEBENSON, Dora dir., LOs tratados de Arquitectura". Madrid, Hermann Blume, 1988. BONET CorREA, A., "Figuras, modelos e imágenes en los tratadistas españoles". Madrid, Alianza, 1993. 


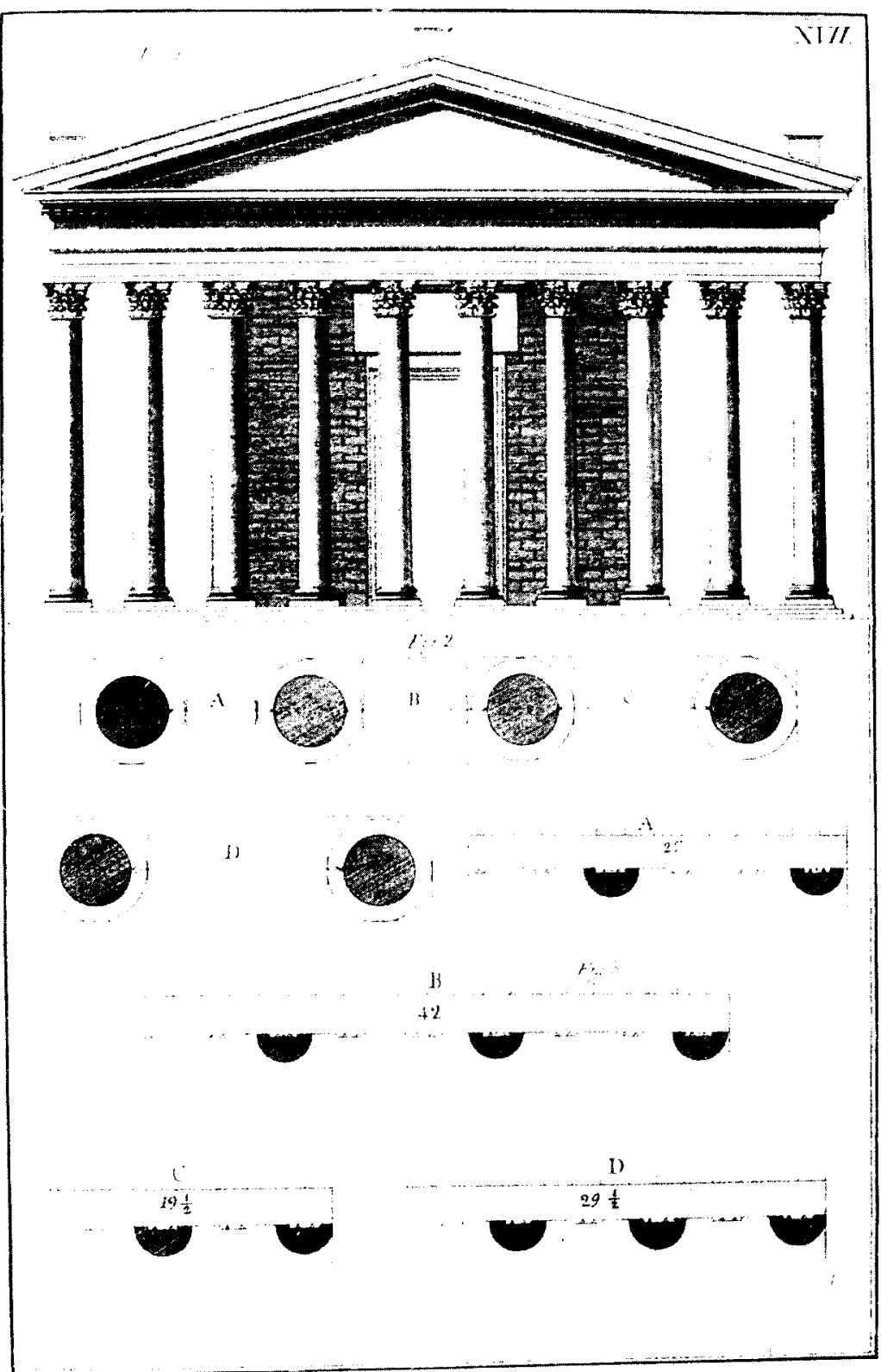

Lám. III: Lámina XVII de la edición de 1787 del tratado de Vitruvio por Ortiz y Sanz. Alzado de templo hypetro. 

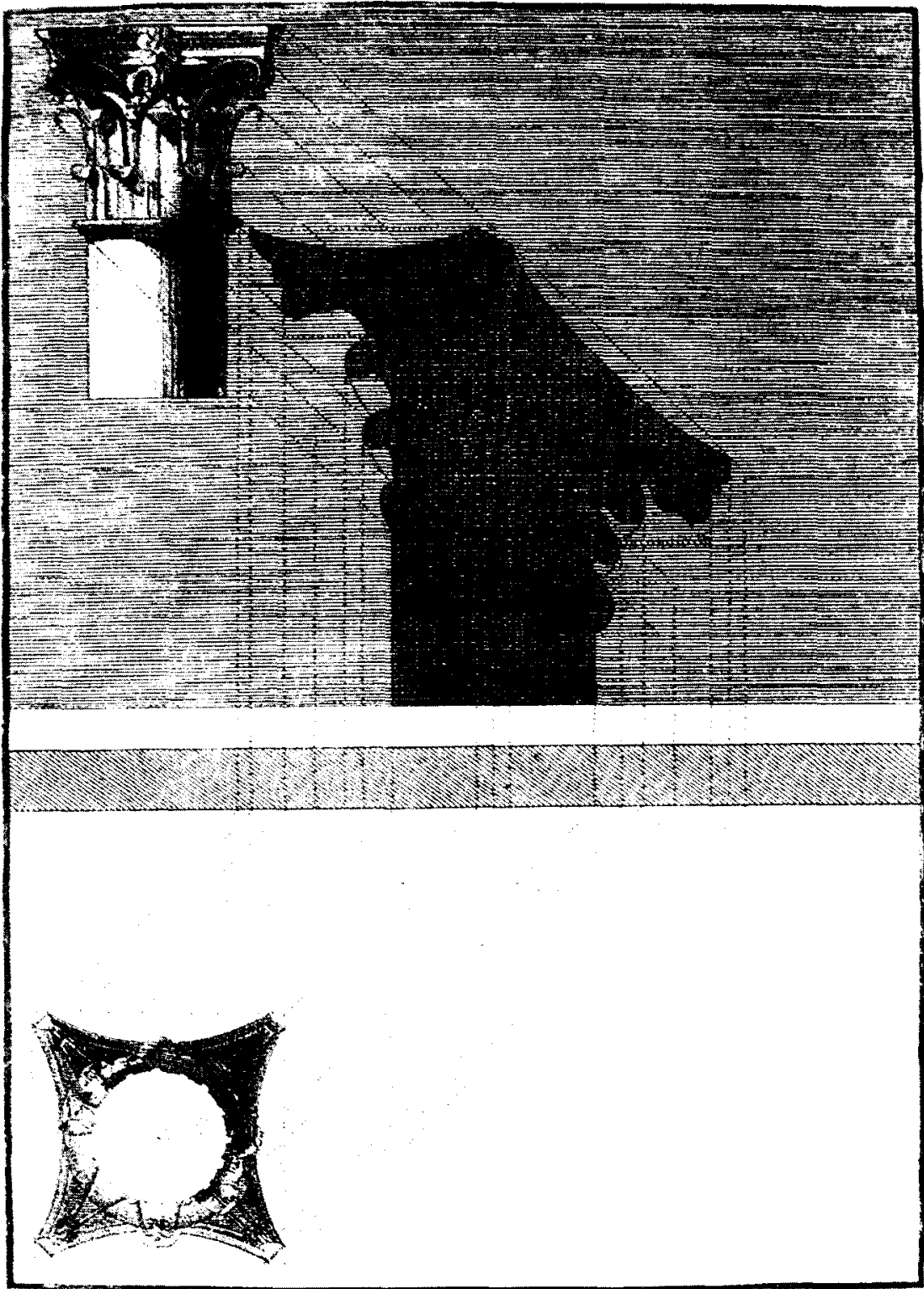

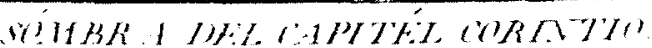

Lám. IV: Sombra del capitel corintic. Traducción de 1792 del tratado de Vignola según Delagardette. 
en la Inglaterra de la llustración, uno de los orígenes del romanticismo. El tratado de este discípulo de Miguel Ángel, que se publicó en Venecia en 1570, ha sido considerado por la historiografía como una sintesis de la Antigüedad clásica, a la cual sometió a una crítica ideológica y tipológica, pero sin llegar a una ruptura profunda, con la arquitectura propia del "Cinquecento". En esta obra se proporcionan modelos de villas y de palacios urbanos, que tuvieron una gran influencia durante los siglos XVII y XVIII. Palladio concedió una función principal a la columna exenta e ideó el denominado "tramo rítmico". Con este motivo arquitectónico el paduano buscó la armonía por medio de la repetición de un tema constructivo, en el cual asocia el arquitrabe al arco, las columnas de dos tamaños y las masas con los macizos, creando, así, fuertes contrastes lumínicos. Sus proyectos se someten rigurosamente a las leyes de la simetría y de la perspectiva. Creó de esta forma una arquitectura muy elegante, basada en un sistema racionalista, con unas líneas muy severas.

La versión de 1797 de Ortiz y Sanz del libro de Palladio era una vez más totalmente oportuna al proporcionar ahora a la Academia otro instrumento imprescindible de trabajo con el enriquecimiento del repertorio de las tipologías arquitectónicas y de sus mismas formas (lám. V). Pero, además, lo hizo en un momento, durante el cual parecía cuestionarse la autoridad vitruviana al ser comparada su teoría con los restos de la Antigüedad y al darse cuenta, que en muchas ocasiones no había correspondencia exacta entre esa teoría y la práctica misma. Ortiz aportó una vez más un nuevo modelo al clasicismo más internacional y actualizado, que en cierta forma podría considerarse como la visión renacentista de ese credo, pero ahora recreado y tomado con más libertad. Así, los lenguajes del clasicismo se enriquecieron y diversificaron. Se interfirió en la lectura filológica y arqueológica de la Antigüedad, que el erudito valenciano había dado una década antes intentando ser totalmente veraz, la importante óptica del Renacimiento italiano. De esta forma se pasó de la unidad a la diversidad de conceptos, y de lo unívoco a lo equívoco. Esta recreación era totalmente oportuna entonces en España, si no se quería llegar a un callejón sin salida, y en cierto modo precipitó al historicismo, y a la libertad y variedad romántica. Se proporcionaba un concepto más recreativo e interpretativo del clasicismo, que superaba el arqueológico, filológico e imitativo.

En este mismio año de 1797 se publicó el tratado «Los diez libros de arquitectura" de Alberti, cuya aparición iba en la misma línea que la reedición del libro de Palladio. Así, en las postrimerías del siglo XVIII se disponía ya en España de reediciones importantes de los principales textos del clasicismo, vieja aspiración académica. En muy pocos años se había 


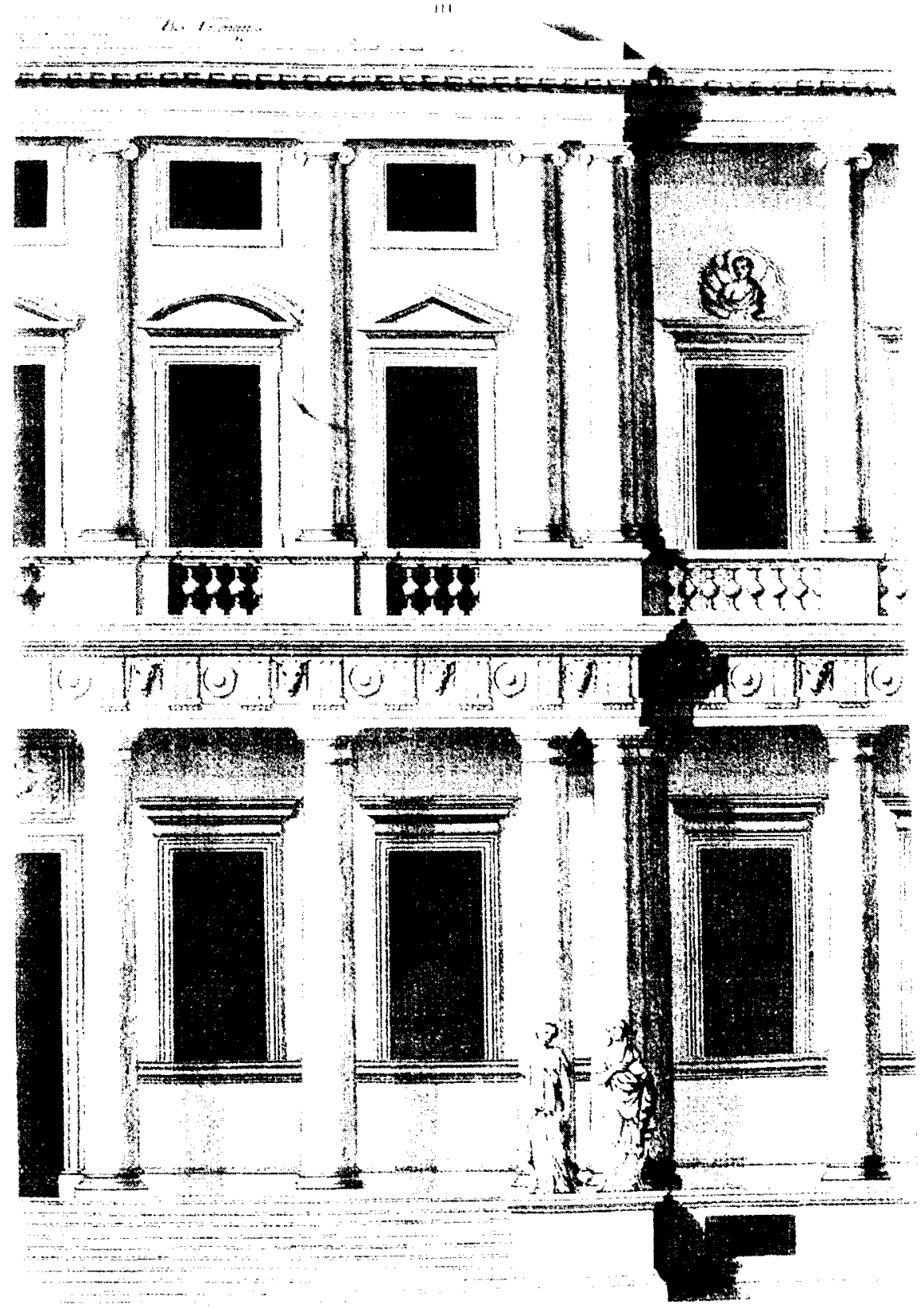

Lám. V: Lámina de la edición del tratado de Palladio por Ortiz y Sanz del año 1797. 
pasado de tener el código vitruviano como casi el único modelo utilizable a la disponibilidad real de otros tratados. Se llegaba a una visión historicista de los diversos clasicismos. El libro de Alberti había sido publicado en latín, y sin estampas en Florencia en 1485, pocos años después de haber fallecido su autor. Basándose en textos clásicos y en sus conocimientos de las ruinas de la Antigüedad, los propios de un arqueólogo, Alberti elaboró toda una teoría arquitectónica al modo vitruviano, pero sin copiarle, en donde también se manifiesta su experiencia personal como arquitecto. Trató de conjugar la teoría con la praxis, auténtica obsesión del clasicismo. Su modernidad le hizo fijarse en el entorno paisajístico, en el que se había de construir todo edificio, y en la ciudad misma, asi como en el clima, y en la higiene y conducción de aguas. Le preocuparon, además, las nuevas tipologías arquitectónicas como es el caso del hospital y de la prisión humanitaria.

La Academia intentó casi desde sus mismos orígenes publicar sus propios textos. Ya en 1752 se encargó a Ventura Rodríguez (lám. II) y a José de Hermosilla la redacción de un tratado de los principios y figuras de la Geometría. Con las dos cartillas elaboradas por ambos arquitectos el Conde de Saceda, ayudado por el jesuitas Berlinger, intentó confeccionar un nuevo tratado; pero su impresión se suspendió. Los Estatutos de 1757 disponían la formación de un curso de Arquitectura, motivo por el cual en este mismo año el Conde de Aranda escribió su plan de estudios con la idea de repartir entre los arquitectos de la Academia los distintos temas para su redacción. Un año después la junta particular aprobó el proyecto del secretario Ignacio de Hermosilla de realizar una sintesis de los mejores autores de arquitectura, ofreciéndose a traducir textos; pero los arquitectos consideraron impracticable la idea, ofreciéndose a realizar el tratado de forma personal. Castañeda y Diego de Villanueva debieron escribir algo; pero ni Ventura Rodríguez ni González Velázquez entregaron trabajo alguno, cuando el secretario se lo reclamó en 1762. Castañeda realizó un tratado de aritmética y geometría en 1766 , que no se publicó al fallecer durante ese mismo año ${ }^{29}$.

Al margen de la Academia se publicó en el crucial año de 1792 las "Instituciones de arquitectura". Francisco Antonio Valzania, un racionalista convencido, se propuso la finalidad de formar el buen gusto por medio de un método analítico al facilitar al lector los conocimientos suficientes

\footnotetext{
29 Muy importantes para conocer la labor publicistica de la Academia son los cinformes sobre los trabajos de la Academia desde su fundación», redactados por Juan Pascual COLOMER. Se pueden datar entre 1815 y 1835 . AASF: leg. $25-4 / 1$
} 
para adquirir capacidad de valorar los méritos de los edificios. Deseaba revisar, cuestionándolas, las ideas mal fundadas difundidas en la tratadística, pues se trataban de conceptos derivados de la sola práctica o de principios mal establecidos. El aspecto más significativo de esta obra era la heterodoxia vitruviana del autor, aunque considerase a Vitruvio como el padre de la arquitectura, pues algunas veces disentía abiertamente de sus normas, de sus principios, al manifestar, peligroso razonamiento en esta época, que la «autoridad no estaba nunca por encima de la razón», pues ésta debía dirigir los juicios. Sostuvo la idea de que la belleza arquitectónica no consistía tan solo en la reproducción de los ordenes clásicos. Propuso que se inventaran otros basados en las leyes de la simetría y de las proporciones. Admitía diversos géneros de ornatos y criticó la extremada esterilidad y desnudez de los edificios en su época bajo la idea del restablecimiento de la buena arquitectura.

\section{LAS PENSIONES DE LA ACADEMIA. ROMA COMO CIUDAD DE ENCUENTROS}

Los nuevos descubrimientos fomentaron los viajes a los lugares «sagrados" del clasicismo, donde se dieron cita tanto los eruditos como los artistas de los paises más distantes entre sí. Alli estudiaron, midieron científicamente las ruinas y se inspiraron en estos modelos; pero al mismo tiempo se relacionaron entre sí, convivieron, debatieron y crearon las bases internacionales del "verdadero estilo» bajo el deseo de someter el arte a un conjunto de reglas universales y atemporales, eternamente válidas. En el entorno cronológico de 1750, momento en el cual se formularon los principales postulados para lograr una nueva arquitectura basada en el racionalismo, Roma, auténtico laberinto de la cultura y del arte, se constituyó en un lugar de citas ineludible y en una base para recorrer toda Italia. La ciudad ofrecía a los viajeros una auténtica síntesis de la historia artística, pues a los restos de la Antigüedad - a las ruinas poéticamente evocadoras consideradas como un canon sublime incuestionable o analizadas crítica y racionalmente- se sumaban modelos de tiempos más recientes. renacentistas, una visión renovada del clasicismo, y barrocos clasicistas ahora a la vez admirados y puestos en entredicho.

Las pensiones en Roma fueron creadas por la Academia en 1745 para que sus discipulos completasen los estudios en esta ciudad. Entonces se dotaron seis plazas, de las cuales dos correspondian a la arquitectura. Los dos primeros arquitectos que acudieron fueron Miguel Fernández y José de Hermosilla, por nombramiento real, aunque las oposiciones las 
ganasen Diego de Villanueva y Alejandro González Velázquez. Los arquitectos debian dedicarse, además de al estudio de los libros, a observar las célebres ruinas y monumentos de la antigüedad, a diseñarlas y reconstruirlas, y a asistir a la construcción de los edificios, que pudieran según indicaban los Estatutos de 1755.

En esta ciudad estaba entonces pensionado por la Academia de Madrid el ingeniero militar José de Hermosilla, quien al volver a España en 1752 , tal y como ocurrió con los demás eruditos y artistas al retornar a sus países de origen, llevó en su bagaje intelectual la visión de la Antigüedad y la información suficiente sobre la práctica arquitectónica internacional de la época. Además de completar su formación bajo el asesoramiento de Fuga redactó un tratado de arquitectura, que quedó inédito ${ }^{30}$. Otro español, Juan de Villanueva, el arquitecto más importante de la llustración española, también amplió sus estudios en Roma, en coincidencia con Domingo Loys de Monteagudo, entre 1759 y 1765 , entrando en conocimiento directo con el legado clásico. Allí dibujó, entre otros edificios, el arco de Tito, y los templos de la Sibila en Tívoli, de Júpiter Stator y de Júpiter Tronante, que remitió a la Academia, el instituto que le becó, para que sirvieran de modelos a los discípulos ${ }^{31}$. También Goya viajó a sus expensas a Italia sin ninguna pensión académica hacia finales de 1768 y hasta mediados de 1771. Durante su estancia conoció al pintor polaco Tadeo Kuntz, seguidor de Corrado Giaquinto; muy posiblemente, se relacionó con el arquitecto y grabador Piranesi, y entabló amistad con el erudito Nicolás de Azara, embajador de España en Roma. Algunos años más tarde otro arquitecto español, Silvestre Pérez, estuvo pensionado por la Academia en la ciudad entre 1791 y 1796 . Remitió dibujos de la villa Tiburtina de Mecenas y del teatro Marcelo, que fueron acogidos con auténtica expectación en los medios académicos.

El filólogo y literato José Ortiz y Sanz también marchó a Roma en 1778 después de vender todos sus bienes con la idea obsesiva de hacer una traducción de la obra de Vitruvio, inspirada por el ambiente académico valericiano que echaba en falta una edición actualizada de este tratado. Allí permaneció hasta 1784 cotejando textos latinos, consultando bibliografía, y estudiando y midiendo las ruinas romanas.

Rolriciue z Rulz. D. "De la utopia a la Academia: El tratado de Arquitectura civil de José de Hermosilla". Fragmentos, num. 3. Madrid. Ministerio de Cultura. 1984. págs. 55-80.

Sobre Juan de Villanueva en la Academia: AASF: leg.: 43-1/1. GARcin Mrı tro. J., "Goya y Juan de Villanueva en la Academia". Reales Sitios. Madrid. Patrimonio Nacional. 1996, págs. $12-22$. 
Los viajes a Roma daban una indudable reputación a los artistas españoles. En la ciudad se formaban en el clasicismo ${ }^{32}$. La Real Academia de San Fernando becó desde 1745 a sus principales discípulos en Italia, después de haber completado su formación en ella y de realizar una oposición, encargando de su vigilancia al académico Francisco Preciado de la Vega como director de pensionados. La duración máxima se fijó en seis años, comprometiéndose el instituto a conducirlos a Roma, mantenerlos y volverlos a la Corte. Los pensionados debían enviar cada año a la Academia los trabajos realizados para que se comprobasen sus progresos artísticos y sirvieran de ejemplos. Los pintores copiaban sobre todo obras de Rafael por consejo de Mengs, mientras que los escultores las hacian de los modelos de la Antigüedad y de maestros barrocos como Algardi o Bernini.

En Roma los discípulos de la Academia madrileña entraron en contacto con otros extranjeros. De interés es su relación con los alumnos de la Academia de Francia en esta ciudad. También se percibe en su formación la huella de la Academia de San Lucca. Desconcertante debió ser el conocimiento de la obra grabada de Piranesi sobre los restos romanos.

Pero algunos artistas también completaron su formación en París. Si los pintores, escultores y arquitectos eran pensionados en Roma, los grabadores estudiaban en esa ciudad. El conde de Floridablanca mandó en 1791 que solo los arquitectos fuesen becados en Roma, pues pensaba que en la Corte existían suficientes pinturas importantes para el aprendizaje de los pintores.

Aspecto interesante a tener en consideración fue la correspondencia mantenida entre los artistas y eruditos viajeros o residentes en Italia y los intelectuales y políticos del país. Hay en el mundo cultural de la llustración una auténtica tela de araña de noticias e ideas que se intercambiaban a través de las cartas entrecruzadas entre eruditos y artistas. Éstas, junto con los libros, los dibujos y los grabados, adquirieron entonces una gran importancia. Es inconcebible este período sin esa correspondencia que acercaba centros culturales distantes. Como ejemplo puede citarse el intercambio de cartas entre Isidoro Bosarte, Secretario de la Academia madrileña, y el arquitecto Silvestre Pérez, el erudito Pedro García de la Huerta y el humanista Nicolás Azara ${ }^{33}$.

Bedat, C., La Real Academia de Bellas Artes de San Fernando...", cap. IV, Los pensicnados en Roma, págs. 249-272

Garcia Melero. J. E., "Cartas a Bosarte desde Roma. (Correspondencia de Pedro Garcia de la Huerta, Azara. Silvestre Pérez y Mengs con el Secretario de ia Academia de San Fernando). 


\section{LOS EXÁMENES DE LA ARQUITECTURA}

En 1781 hubo un importante debate sobre los exámenes de la arquitectura en el que intervinieron profesores tan significativos como Ventura Rodríguez, Juan de Villanueva y Pedro Arnal, así como el consiliario Pedro de Silva ${ }^{34}$. Las profesiones de este arte quedaron divididas según el autor del proyecto del Museo del Prado en cuatro categorias jerárquicas en base a una mayor o menor capacidad intelectual: los académicos de mérito, los arquitectos, los maestros de obras y los oficiales de albañilería, canteros y carpinteros. Los arquitectos se diferenciaban de los maestros de obras, en que, mientras los primeros se ocupaban de obras grandes, los segundos realizaban las viviendas comunes y las obras más pequeñas. Se les consideraba como simples practicones sin capacidad teórica para diseñar edificios realmente importantes. El grado de académico de arquitectura, de incorporación en este centro de las Bellas Artes, se otorgaba a arquitectos de habilidad reconocida y sobresaliente por sus obras, después de realizar una prueba más teórica que práctica en la Academia, aunque el consiliario Pedro de Silva no deseara su proliferación en su escrito de 1792, al cual he aludido antes.

Los exámenes para conseguir el título de arquitecto se reglamentaron por la real orden del 24 de noviembre de $1783^{35}$. En la del 27 de febrero de 1785 se aplicó el mismo sistema a pintores y escultores ${ }^{36}$. Constaban de dos partes distintas: la prueba de pensado y la de repente. La primera consistía en la realización de un asunto elegido por el aspirante a uno de estos títulos de arquitecto y maestro de obras de entre una terna de temas sacados a suerte de un libro de materias. Una vez diseñado el proyecto - con la inclusión de un informe práctico facultativo, que comprendía la ubicación, plantas, fachadas, método constructivo y cálculo de ese proyecto- sería reconocido por los profesores. En el caso de haber sido admitido, podría presentarse al ejercicio de repente, convocado por la junta ordinaria, aislado el pretendiente en una sala de la Academia durante un tiempo fijo, no superior a quince horas, después de elegir otro tema de entre tres salidos al azar. A continuación se examinaría al can-

Academia. núm. 70. Madrid. Real Acadentia de Bellas Artes de San Fernando, primer semestre de 1990, págs $337-382$

AASF: leg. 17-3/1. En este legajo se hallan todos los informes de los arquitectos. Garacia Mt. ERo. J. E.. El debate académico sobre los exámenes...

La Real orden fue recogida en las actas de la junta ordinaria del 7 de diciembre de 1783.

AASF: Libro de juntas generales (1774-1785): 3/84, fol. 235 anv.-236 anv

Real orden de 17 de febrero de 1785, firmada por el Conde de Floridablanca sobre la creación de académicos de mérito de pintura y escultura. AASF: leg.: 17-3/1. 
didato sobre el dibujo hecho en la prueba de repente, el proyecto previo de pensado y acerca de las materias propias de la profesión tanto en la parte teórica como en la práctica ${ }^{37}$.

Por la real orden de 23 de mayo de 1800, firmada por Mariano Luis de Urquijo, se dispusieron los requisitos que todo maestro arquitecto - denominación dada por el Rey el 18 de noviembre de 1793, suprimiendo la profesión de maestro de obras- debía poseer para acceder a académico de mérito como grado de incorporación a la Academia. Debía ser sujeto bien opinado tanto en la parte moral como facultativa - se respetaba en este sentido la opinión de Ventura Rodríguez de 1781-, haber pasado un informe favorable de las obras presentadas a la Comisión de arquitectura, debería escribir un discurso o disertación sobre algún tema de su arte señalado por este instituto, habría de dar razón por escrito sobre las preguntas o reparos que se le hicieran, y, una vez aprobado tal escrito, pasar la votación secreta ${ }^{38}$

Faltaba por definir el método, o reglamento, más conveniente a seguir en adelante en las pruebas para otorgar el nuevo título de maestro arquitecto, que los académicos estudiaron en la junta ordinaria del 7 de junio de $1801^{39}$. Sus acuerdos se promulgaron literalmente en la real orden del 29 de julio de 1801 . Pero, en realidad, lo aportado con relación al antiguo sistema empleado en los examenes de arquitectos no era, - apenas aportaba, nada nuevo. Llama !a atención la importancia que se concede al cálculo detallado del coste que tendría el edificio proyectado en la prueba de pensado, si se hubiera de construir en el sitio, donde se lo imaginaba su autor. También debía indicar su método de construcción. El juicio de valor sobre los diseños se haría en la junta de Comisión de arquitectura, que asumió esta función; pero sus opiniones pasarían siempre por la junta ordinaria siguiente de la Academia. Aprobada la prueba inicial, debería presentar certificaciones de práctica siempre bajo la dirección de un arquitecto aprobado, antes de pasar al examen llamado de repente. El examen conjunto de ambos ejercícios, así como la contestación del aspirante a preguntas teóricas y prácticas, se llevaría a término el jueves siguiente al día de la prueba de repente y, si fuera festivo, el sá-

GAficia MEIFRO. J.E., "El debate académico sobre los exámenes...", págs. 371-372. También en: Garcia MELERO. J. E.. "Arquitectura y burocracia: el proceso del proyecto en la Comisión de Arquitectura de la Academia (1786-1808)". Espacio, tiempo y forma, serie Vil, núm. 4. Madrid UNED. 1991, págs. 283-348. Vid págs. 293-294

Actas de la junta ordinaria de 4 de mayo de 1800. AASF: $3 / 86$, fol. 138 anv. y rev. Actas de la junta ordinaria de 1 de junio de 1800 . AASF: $3 / 86$, fols. 139 rev. -140 anv.

Actas de la junta ordinaria del 7 de junio de 1801. AASF: 3/86, fol 160 anv 
bado. Su aprobación o desaprobación se notificaría por el secretario a la junta ordinaria más próxima.

En esta reunión se acordó, además, la realización de un libro de temas de arquitectura. Para ello se copiarían, numerándolos, los asuntos de los libros de acuerdos de la Academia, que hasta entonces se habian empleado para examinar a los arquitectos. Este volúmen se encerraría bajo llave en la mesa de la sala de juntas desde que se concluyera la ordinaria hasta la mañana del día, que se presentase el aspirante ${ }^{40}$.

Quedaba por definir qué se haría con los antiguos maestros de obras con facultades restrictivas, profesión suprimida desde 1793. Por la real orden se les dejaba la opción de sujetarse a las mismas pruebas y examenes, que las de los demás candidatos a maestros arquitectos. Si aprobaban, gozarían de todas las facultades del arte.

\section{LOS PROFESORES DE ARQUITECTURA EN LA COMISIÓN (1786-1791)}

La carta circular del 23 de noviembre de 1777, por la que se obligaba a enviar a la Academia madrileña cuantos proyectos de obras públicas de importancia se hicieran en España para su censura, y la posterior creación de la Comisión de arquitectura por la real orden del 22 de marzo de 1786 propiciaron la adaptación de los arquitectos académicos a la realización de otras tareas importantes dentro del instituto, además de la docente, después de una fase de ensayo ${ }^{41}$. Apareció, así, un nuevo profesional, cuyo prototipo se fue definiendo durante esos cerca de nueve años. Si las polémicas por diversos motivos entre Ventura Rodríguez y Diego de Villanueva, un práctico y un teórico, habian delimitado en parte las relaciones anteriores entre los profesores de arquitectura, ahora el sistema cambiaría bastante al tener que asumir conjuntamente una actitud colegiada ante la censura de tales obras públicas, donde lo individual apenas tenia cabida. Se debia trabajar en grupo

Un análisis sobre este libro de temas de examenes (AASF: 333/3) se puede hallar en: Santamarzia Almolda, M". R. "Bases documentales para el estudio de la teoría arquitectónica (1814-1858) en la Real Academia de Bellas Artes de San Fernando". Espacio, tiempo y forma. serie VII, t. 9 . Madrid. UNED. 1996, págs. 219-247. Se indican los exámenes de los 446 arquitectos aprobados por la Academia durante este periodo, localizándose sus expedientes y ejercícios en el archivo de este instituto madrileño.

La Real orden. firmada por el Conde de Floridablanca y dirigida al viceprotector Marqués de la Florida se halla en AASF: leg.: 18-9/1. Fue leída en la junta ordinaria del 2 de abril de 1786 AASF: $3 / 85$, fols. 9 anv. -10 anv. También en la junta particular del 6 de abril. AASF: 3/124, fol. 9 anv. -11 anv. 
La muerte de Ventura Rodríguez acaecida el 26 de agosto de 1785, pocos meses antes de crearse dicha Comisión, también debió influir, pienso, en tal cambio ${ }^{42}$. Junto a Marcos de Vierna había realizado antes una labor de censura de obras públicas para el Consejo. Con su fallecimiento, y el anterior de Diego de Villanueva en 1774, desaparecía en la Academia la generación transicional de arquitectos formados en las obras barrococlasicistas del Palacio Real nuevo de Madrid. Ambas fechas, 1774 y 1785 , delimitan un período de renovación en la mayoría de los empleos docentes de la arquitectura, que coincide con una fase de especial actividad política y de desarrollo ideológico del instituto bajo el protectorado del Conde de Floridablanca, primer secretario de Estado, aproximadamente, entre 1777 y 1791. En esta fase la Academia asumió plenamente tareas de centralización y de control de las obras públicas. Consiguió cierta independencia con respecto al Consejo de Castilla, al que sustituyó en tal actividad, y se constituyó en organismo dependiente directamente del Rey, al reflejar y realizar toda su ideología política absolutista e ilustrada. Pero también se creó una burocracia.

Tales sustituciones de los profesores constituyeron un factor imfortante de renovación dentro de la tradición, pues facilitó el acceso a este organismo de arquitectos formados en las distintas escuelas de la Academia, aún siguiendo siempre el hilo conductor de la generación anterior. Los nuevos directores y tenientes directores fueron quienes establecieron los parámetros teóricos y prácticos, que pondrian en marcha la máquina censoria de dicha Comisión al participar bastante activamente muchos de ellos en estas juntas durante varios años. No serían, por lo general, arquitectos, cuya estrella brillara de una forma muy significativa por su actividad práctica individual. Destacaron sobre todo por su labor cotidiana conjunta como equipo de arquitectos colegiados al servicio de la ideología de la Academia, en cuya formación también participaron junto con los consiliarios aristócratas y literatos, a quienes asesoraban por medio de informes técnicos. Cumplieron una triple tarea: difundir el clasicismo, velar por la economía en la arquitectura y marginar a los arquitectos gremiales.

Lo ocurrido en 1786 admite en cierto modo una comparación, con lo que después sucedería ya en el año crítico de 1792. La renovación ofreció entonces más un carácter político que propiamente pedagógico, pues los nuevos nombramientos incidieron especialmente sobre el vértice mismo de este centro de las Bellas Artes: al protector, viceprotector, secretario, vi-

\footnotetext{
El fallecimiento de Ventura Rodriguez fue comunicado oficialmente por Antonio Pcnz a la Academia en la junta ordinaria del 4 de septiembre de 1785. AASF:3/84, fol. 292 rev.
} 
cesecretario, director general... Por el contrario, en este momento los cambios afectaron más a los profesores, y promovieron a los nuevos directores y tenientes directores de arquitectura, quienes tuvieron a su cargo el quehacer censor facultativo de la Comisión.

La mayoría de los nuevos profesores habían sido formados en gran parte por los fallecidos Ventura Rodríguez y Diego de Villanueva en la Academia, $y$, asimismo, adquirieron práctica en el estudio de aquél, tal vez el más importante del momento. Pero ya aportaron nuevas ideas plenamente clasicistas e internacionales al haber viajado muchos de ellos a Roma para completar su formación y contar, además, con la traducción y publicación en España de varios tratados del clasicismo, que les valieron siempre de referencia y cita, y conocer la bibliografía arquitectónica italiana y francesa de la época.

La labor realizada por esta generación de arquitectos del primer período de actividad de la Comisión de arquitectura, que accedió a los empleos docentes de la Academia en el entorno cronológico de ese año fundacional de 1786, fue seguramente bastante menos brillante a un nivel individual, si se exceptúa la actividad de Juan de Villanueva casi siempre al servicio del Rey, quien en parte se marginó y fue desplazado al mismo tiempo de ella, asistiendo a muy pocas de sus primeras juntas. Sin embargo, resultó especialmente tenaz, laboriosa y efectiva como conjunto dentro de la Academia. Se puede decir de ellos, que fueron en gran medida los grandes sacrificados por la vida académica con la realización de un quehacer tan trabajoso como anónimo, que les quitaba casi todo protagonismo.

A esta primera generación de arquitectos académicos de la etapa inicial de la Comisión de arquitectura les correspondió vivir una época de grave crisis ideológica a un nivel general, aunque este centro tuviese ya elaboradas las líneas maestras de su programa teórico y de actuación, tarea realizada algunos años antes, sobre todo, en la fase de las representaciones al Rey, entre 1768 y 1777 . Las ideas revolucionarias del 89 francés propiciaron esta crisis ideológica al ver hundido el modelo cultural galo de intervención en el campo del arte al mismo tiempo que la llustración parecia entrar en una etapa de conflicto inicial, surgiendo los principios ideológicos propios de una nueva mentalidad romántica. Las ideas de libertad, de igualdad y de fraternidad tuvieron sus ecos en la misma Academia, que entre 1792 y 1793 , siendo viceprotector el culto y timorato Bernardo de Iriarte, soportó una serie de conflictos importantes para después retornar, o intentarlo, al orden ${ }^{43}$

43 Gafcia Melero, J. E.. Úbeda de los Cobos, A..., "Renovación, crisis, continuismo. La Real Academia de San Fernando en 1792. Madrid, Real Academia de Bellas Artes de San Fernando, 1992. 
Pero, además, la actividad arquitectónica de estos profesores y su labor de censura tuvo que acomodarse a un grave momento de inflación por el que atravesó la economía del Reino especialmente en 1788-89 con el alza de los precios del grano y, sobre todo, en 1793 durante la guerra con Francia, que motivó un importante déficit ${ }^{44}$. Ello provocó que durante este periodo ya casi de final del siglo de la llustración se realizaran, considerando siempre el conjunto, pocas obras públicas de cierta envergadura artística; pero, no obstante, se llevaron a cabo una gran cantidad de obras "menores" de carácter muy pragmático, casi cotidiano. Sin embargo, las características de pragmatismo y cotidianidad de estas obras públicas constituyen, sin ninguna duda, dos elementos que acentuaron la importancia de esas construcciones por su incidencia directa en la sociedad de la época y por ser reflejo fiel de los ideales culturales, sociales, políticos y económicos de finales de la llustración. La construcción de puentes, de caminos, de escuelas, de ayuntamientos, de cárceles, de pósitos, de teatros... certifican hasta qué punto se trataba de realizar ahora materialmente tales ideas ${ }^{45}$.

Entre diciembre de 1785 y mayo de 1786 hubo una serie de nombramientos de profesores de arquitectura, que cambiaron totalmente el cuadro docente de este arte en la Academia. Ellos serían quienes pondrían en marcha la máquina censoria de la Comisión. Así, Juan de Villanueva, que entonces era el teniente director más antiguo, fue nombrado director honorario - Sabatini no lo sería hasta la real orden del 11 de abril de $1791^{46}$ con antigüedad y precedencia de asiento al que designase actual por una real orden del 29 de diciembre de 1785, que se leyó en la junta particular del 8 de enero de $1786{ }^{47}$. El 20 de febrero de 1786 se designó a Pedro Arnal, quien hasta entonces ocupaba el empleo de teniente director segundo, segundo director ${ }^{48}$. Los académicos de mérito Manuel Martín

Herr, R., España y la revolución del siglo xvill. Madrid, Aguilar, 1964. págs. 317-321

Gafcia Melero, J.E., "Los puentes y la Comisión de arquitectura (1786-1808)". En Espacio tiempo y torma. serie VII. núm. 9. págs. 189-217. Madrid. U.N.E.D.. 1996. En este artículo analicé y cuantifiqué las tipologias de obras públicas objeto de censura por la Comisión.

Se solicitó tal cargo honorifico para Sabatini en la junta particular del 3 de abril de 1791 AASF: $124 / 3$, fol. $163 \mathrm{rev} .-164$ anv. (Actas).

Actas de la junta particular del 8 de enero de 1786. AASF: $3 / 124$, fol. 1 anv.

En la junta particular del 8 de enero de 1786 y en virtud del nombramiento de Juan de Villanueva como director honorario. se acordó proponer como segundo director de arquitectura para la ordinaria inmediata, tal y como exigian los Estatutos. en primer lugar al teniente director segundo Pedro Arnal. a continuación al académico de merito Manuel Martin Rodríguez y. por último, a Francisco Sánchez. AASF: 3/124, fol. 2 anv. En la votación celebrada en la junta ordinaria del 8 de febrero fue elegido Arnal. quien obtuvo 17 votos secretos a favor frente a uno sólo que tanto Rodriguez como Sánchez consiguieron respectivamente. AASF: 3/85. El nombramiento, fechado el 20 de febrero, fue leído en la junta ordinaria del 5 de marzo. AASF: $3 / 85$. fol. 5 . 
Rodríguez y Francisco Sánchez fueron nombrados respectivamente primer y segundo tenientes en marzo y 21 de mayo de $1786{ }^{49}$.

No obstante, el fallecimiento de Miguel Fernández hizo que en octubre de 1786 se corriera de nuevo el escalafón de los profesores de arquitectura. Pedro Arnal pasó a ser primer director; Manuel Martín Rodríguez fue el segundo desde el 11 de noviembre de 1786; Francisco Sánchez ocuparía la primer plaza de teniente director y para la segunda se nombró a Manuel Machuca ya el 20 de enero de 1787. Pero como Miguel Fernández, quien fue un competente profesor, hubiera ocupado al mismo tiempo las plazas de director de arquitectura y de perspectiva, se procedió en la junta particular del 5 de noviembre a elegir al académico de mérito que le reemplazara en esta segunda obligación. Guillermo Casanova fue el elegido.

En este nuevo cuadro docente de la arquitectura de la Academia, surgido al ponerse en marcha la Comisión entre los años 1786 y 1787, se aprecia una diversidad de escuelas de procedencia, pues, aunque se formaran preferentemente con algún profesor determinado, colaboraron después con otros. No obstante, sobre la mayoría de ellos se proyectaba la sombra de Ventura Rodríguez, el arquitecto que en estos momentos era el más recordado por su prestigio dentro de este instituto, apreciándose el hecho mismo de haber trabajado con él como una espléndida carta de presentación (lám. VI). Se pueden considerar a José Moreno, Manuel Martín Rodríguez, al parecer su hijo, Francisco Sánchez y Manuel Machuca discípulos suyos en algún momento de sus vidas ${ }^{50}$. Así, Sánchez estudió bajo la dirección directa del arquitecto de Ciempozuelos, quien le escogió entre sus alumnos para que le acompañase en calidad de delineador al ser nombrado por orden del Supremo Consejo Real para realizar los reconocimientos de las catedrales de Andalucía.

Al vacar los dos empleos de tenientes directores de arquitectura la junta particular del 5 de febrero de 1786 propuso para la votación secreta, que se debia celebrar en la ordinaria siguiente, a los académicos de mérito Manuel Martín Rodriguez. Francisco Sánchez y José Moreno por este orden. AAS F: 3/124, fol. 2 rev.. Pero tal disposición no debió agradar al estamento de académicos de mérito, quizá porque rompía con el escaláón de antigüedad, pues varios de ellos presentaron instancias solicitando a la junta particular que se les tuviese en consideración para cubrir el empleo de teniente director de arquitectura. Elías Martinez, Manuel Machuca, Antonio González Velázquez, Ignacio Tomás, Manuel Turrillo y Altonso Regalado Rodríguez enviaron sus respectivos memoriales. No obstante, la junta particular del 5 de marzo confirmó su juicio del mes anterior, proponiendo a Manuel Martín y a Francisco Sánchez, aunque se sustituyó a José Moreno por Manuel Machuca para el tercer lugar. AASF: $3 / 124$, fol. 4 anv.

Carlos SAMBAIClO amplia considerablemente estos discipulos en su artículo "Datos sobre los discipulos y seguidores de D. Ventura Rodríguez". En Estudios sobre Ventura Rodriguez (1717-1785). Madrid. Real Academia de Bellas Artes de San Fernando, 1985, págs. 243-304 


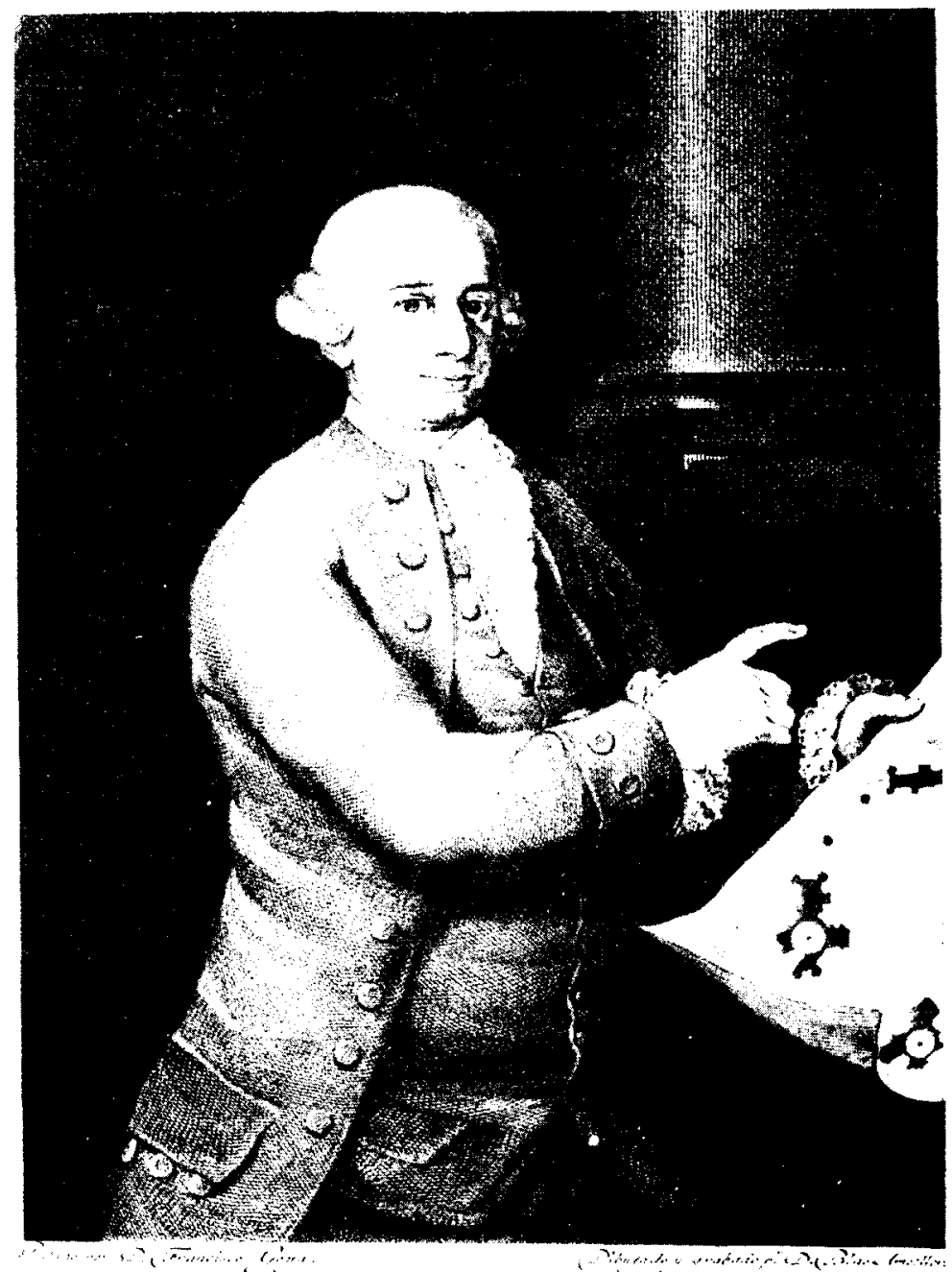

DON VENTURA RODRIGULE,

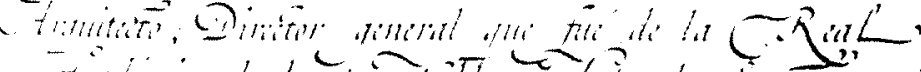

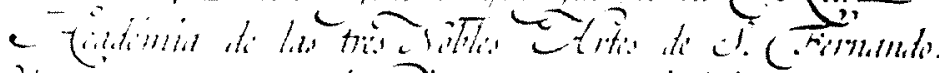

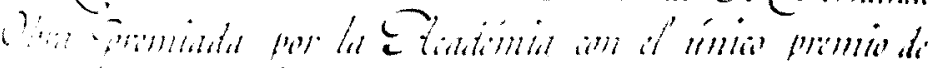

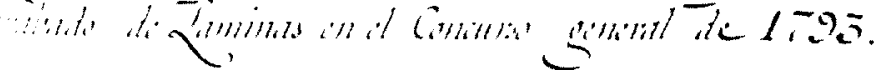

30

Lám. VI: Retrato de Ventura Rodriguez. Grabado de Blas Ametler. 
Tampoco faltaban los alumnos y colaboradores de Sabatini, como Miguel Fernández, el más antiguo de todos ellos, y el propio Sánchez. También se insinúa la línea de José de Hermosilla en Pedro Arnal, delineador de los dibujos de la Alhambra bajo su dirección junto con Juan de Villanueva, y formado, no obstante, en Toulouse, y en el propio Francisco Sánchez, quien trabajó a las ordenes del capitán de ingenieros en el arreglo del paseo del Prado, sus alcantarillas, desmontes y forma. La escuela, quizá un tanto cerrada en la propia familia, de los Villanueva aparece en esta primera fase de la Comisión de arquitectura con ciertos aires de marginalidad en la Academia - después sería fundamental-, aunque en estos precisos momentos Juan estuviese realizando por encargo real sus obras más importantes y las más significativas de esta época por su mismo grado de representación. Tal vez fuese esa marginalidad, paradójicamente al mismo tiempo voluntaria y obligada, el motivo, que en 1792 le llevó a criticar la gestión de esa Comisión en su famoso informe sobre los estudios en la Academia.

Hay un elemento coincidente en casi todos ellos: el conocimiento teórico-práctico de la arquitectura clásica, aprendida primero a un nivel teórico en la misma Academia, y después en la práctica durante los viajes de muchos de ellos a Roma como pensionados de este instituto de las Bellas Artes. Así, Miguel Fernández permaneció en Italia entre 1747 y 1759; Juan de Villanueva de 1758 a 1764; Manuel Martín Rodríguez en 1776, aunque a costa de Ventura Rodríguez, y Guillermo Casanova de 1779 a 1785. Roma fue el principal centro en el extranjero de formación de los arquitectos de la Comisión de arquitectura; pero la arquitectura francesa de la época influiria poco a poco cada vez más, proporcionando, por una parte, modernidad científica y, por la otra, utopias.

Es significativo que los dos arquitectos más prestigiosos entonces, Francisco Sabatini y Juan de Villanueva (lám. VII), estuvieran honoríficamente vinculados con la Academia desde 1791. El primero ya representaba el ayer, mientras que el segundo estaba en plena actividad arquitectónica. Ambos se relacionaban, además, directamente con los dos principales reyes ilustrados, que habian incrementado el poder de este centro de las Bellas Artes: el uno con Carlos III y el otro con su hijo Carlos IV. Con el nombramiento del italiano se establecía al mismo tiempo un interesante nexo entre la arquitectura y la ingeniería militar dentro de la Academia, tan importante en la época. El prestigio era fundamental para este instituto, así como acrecentar sus vínculos con la realeza. Pero el agobiante y en algo gris trabajo censor y pedagógico, mitad burocrático mitad creativo, para el Estado lo realizaron otros arquitectos quizá más discretos y hasta impersonales, aunque propiamente académicos, quie- 


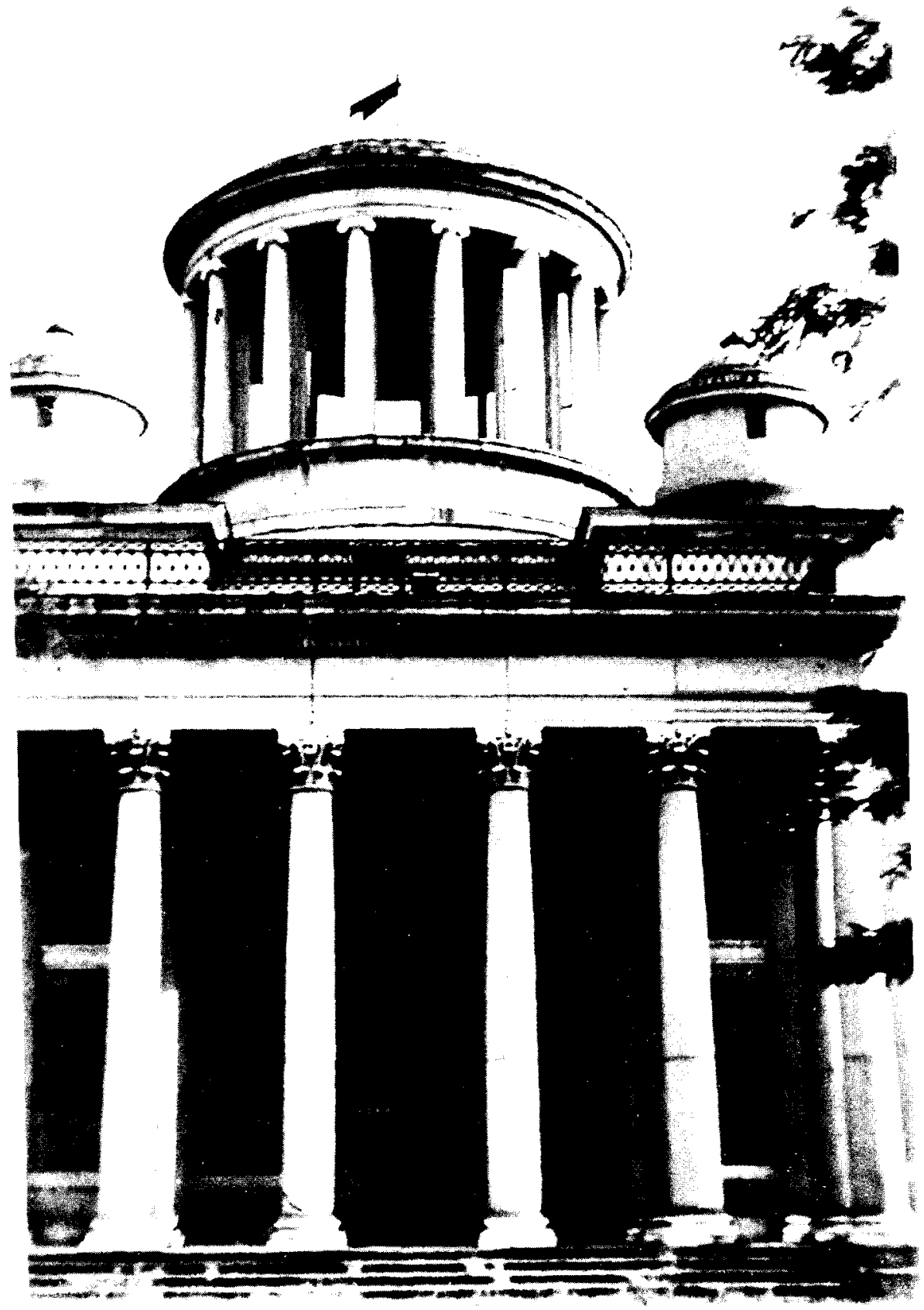

Lám. VIl: Juan de Villanueva: Observatorio astronómico de Madrid. 
nes dictaron y siguieron al mismo tiempo el pensamiento de la Academia en esta labor de censura de tales obras públicas "menores" tan representativas de la llustración. Ellos tuvieron que vincular los conceptos de clasicismo y de economía entre sí.

Este cuadro de profesores se enriqueció al ser nombrado Silvestre Pérez vicesecretario de la Academia al fallecer el pintor Luis Paret el 14 de febrero de 1799. Habia delineado con Manuel Machuca la catedral de Cádiz y había acompañado a Manuel Martín Rodríguez en las comisiones de Covadonga y Pamplona ${ }^{51}$.

\subsection{Las licencias de los profesores}

La creación de la Comisión de arquitectura provocó que algunos de sus profesores de este Arte tuvieran que dejar la Academia para desplazarse a otras localidades del Reino con la misión de cumplir encargos de esta junta de reconocimientos de obras. Tales ausencias obligaban al interesado a pedir licencia a la junta particular, abandonar sus clases, si era su turno, y buscar y proponer sustituto, que cumpliese con su obligación docente. Los académicos de mérito eran las personas encargadas de cubrir estas interinidades.

En el período que nos ocupa de 1786 a 1792 se concedieron cuatro licencias para viajar fuera de la Corte. Manuel Machuca y Vargas, y Guillermo Casanova serían los favorecidos con esta libranza de dar sus clases. Los permisos comprendieron una periodicidad muy variable, que iba desde quince días hasta tres meses, y eran concedidos con mayor beneplácito, si detrás de la obra a reconocer estaba el encargo del Rey o de un noble vinculado de alguna forma con la Academia.

Manuel Machuca tuvo que ausentarse un par de veces de la Academia. Así, en la junta particular del 3 de octubre de 1790 se le permitió abandonar Madrid por serle forzoso hacer reconocimientos en la Villa de Medina del Campo y en Benavente. El académico Ramón Alonso le suplió en sus clases en la Sala de geometría. Sin embargo, los consiliarios le previnieron, acudiendo a su propia prudencia, para que regresase lo antes posible, pues pensaban que la enseñanza pública solía padecer en poder de los sustitutos ${ }^{52}$.

Información sobre Silvestre Pérez en la Academia en AAASF: leg. 39-9/1

Actas de la junta particular del 3 de octubre de 1790. A.A.S.F.: 3/124, fol 144 rev 
Tan sólo algunos meses después, el 28 de enero de 1791, este mismo teniente director volvió a solicitar licencia para ausentarse de la Corte durante un trimestre, al mismo tiempo que pedía un sustituto, para que diese sus clases de geometría, que por alternancia debía impartir en los meses de febrero y de abril. En esta ocasión su itinerario era bastante más complejo. En primer lugar tenía que ir a Cádiz a reconocer las obras de su catedral nueva, pues el Rey le había nombrado su director principal. Después, de regreso a Madrid debía reconocer las iglesias de Ajalvir y Miedes, y las carreteras de Extremadura y Alcalá. Se le concedió el permiso solicitado, nombrándose al académico Blas Cesáreo Martín, para que le reemplazara en dichas clases ${ }^{53}$.

Manuel Machuca y Vargas había sido designado el 16 de agosto de 1787 por real orden dada por el Conde de Floridablanca para que acudiera sin dilación a Cádiz a fin de reconocer las obras de la catedral debido a las discrepancias surgidas entre Miguel de Olivares y José Prat a la hora de levantar la cúpula ${ }^{54}$. Después de viajar a esta ciudad en compañía del joven Silvestre Pérez, Machuca presentó al Rey un informe y la descripción del estado actual de la catedral para su enmienda y conclusión, junto con los diseños respectivos. El Conde de Floridablanca remitió todo el expediente el 4 de febrero de 1790 a la Comisión de arquitectura para que informara, lo que este organismo hizo el 25 de marzo, aprobándolos enteramente ${ }^{55}$. Entonces se decidió que la fábrica de dicha catedral corriera a cargo de un arquitecto director y otro constructor con una serie de facultades respectivas. Con fecha 2 de abril de ese mismo año y por designación real Machuca fue nombrado arquitecto general y Miguel de Olivares, director constructor ${ }^{56}$.

Precisamente en la junta particular del 6 de febrero de 1791 Guillermo Casanova, director de perspectiva, solicitó licencia para los meses de fe-

\footnotetext{
53 Actas de la junta particular del 6 de febrero de 1791. A.A.S.F.: 3/124, fols. 153 rev. 154 anv.

54 Oficio del Conde de Floridablanca a Antonio Ponz, con fecha del 16 de agosto de 1787, indicándole que el Rey había resuelto que Manuel Machuca fuera sin dilación a Cádiz para reconocer las obras de aquella catedral. Pasó por la junta particular del 2 de septiembre de ese mismo año. AASF: 2-32/5.

55 Oficio del Conde de Floridablanca remitiendo a la Comisión de arquitectura el informe y descripción de la catedral de Cádiz, redactados por Manuel Machuca, acompañado por los respectivos diseños. Palacio, 4 de febrero de 1790. A.A.S.F.: leg.: 2-32/5. Fueron aprobados en la junta de dicha Comisión del 5 de marzo de 1790.

56 Oficio del Conde de Floridablanca dirigido a Antonio Ponz informándole de la decisión real de nombrar dos arquitectos: a Manuel Machuca, arquitecto general, y a Miguel de Olivares, director constructor. Está fechado en Palacio el 2 de abril de 1790. A.A.S.F.: leg.: 2-32/5. Se leyó en la junta de la Comisión de arquitectura del 23 de abril de 1790. A.A.S.F.: 3/139, tomol, fol. 139 rev.. Actas firmadas por José Moreno
} 
brero y marzo de dar sus clases con el fin de desplazarse al territorio de las Ordenes Militares para efectuar varios reconocimientos. De nuevo un académico de mérito, Juan Navarro, fue designado para reemplazarle en la labor docente. Pero la junta le recomendó que no dilatase su viaje más del tiempo pedido ${ }^{57}$.

El mismo Casanova tuvo que solicitar otra licencia el 19 de julio de este mismo año. Durante las vacaciones acudió con permiso de la Academia a Villafranca del Bierzo para el replanteo del altar mayor de su colegiata. Pidió ocho o quince dias más de permanencia en esta localidad en el caso de que así lo exigiera el estado de las obras. Sin embargo, prometía estar ya en Madrid para el comienzo del nuevo curso. La junta le dio el permiso, porque tal ocupación había sido recomendada por el Duque de Alba ${ }^{58}$.

\section{LOS ACADÉMICOS DE MÉRITO Y LA COMISIÓN DE ARQUITECTURA}

Los académicos de mérito por la arquitectura desarrollaron una tarea aún más gris, si cabe, que los profesores directores y tenientes directores. Pero su labor resultó muy importante, sustituyéndoles en las tareas docentes en sus ausencias y enfermedades, y ayudándoles en su labor censoria de la Comisión de arquitectura desde su misma fundación por disposición de la real orden fundacional del 22 de marzo de 1786 . En ella se estableció la constitución de estas juntas por el vicesecretario de la Academia, empleo establecido por esta misma cédula, los directores y tenientes directores, y, también de forma indefinida en su número y en su designación personal, por los arquitectos académicos de mérito de este arte, que se desearan añadir. Cumplían, de esta manera, una tarea secundaria y siempre subordinada al «personal fijo» docente del instituto. Las juntas del nuevo servicio se estratificaban, así, jerárquica y piramidalmente entre los distintos arquitectos.

La junta particular del 6 de abril de 1786 trató exclusivamente sobre el procedimiento a emplear para cumplir los deseos de Carlos III al establecer la Comisión. Se acordó agregar a sus reuniones a Francisco Sánchez, Manuel Machuca y Alfonso Regalado Rodríguez, quienes estaban en po-

lbidem, fol. 154 anv

58. Actas de la junta particular del 7 de agosto de 1791 . A.A.S.F.: $3 / 124$, fols. 173 rev. -174 anv. 
sesión de dicho título ${ }^{59}$. Pero al ser nombrados, muy pocos meses después, aquellos dos arquitectos, mencionados en primer y segundo lugar, para desempeñar ambas tenencias de arquitectura, fueron sustituidos en las juntas por otros académicos de mérito, que no habían alcanzado estos empleos en competencia con ellos, pues desde entonces Sánchez y Machuca formarían parte de la Comisión por derecho propio, debido a su calidad de profesores.

Los académicos de mérito fueron, por tanto, auténticos "comodines" para la Academia, que cumplían interinamente tareas diversas para cubrir huecos. Estaban al servicio de los consiliarios y profesores; pero su actividad mayor o menor en el centro dependía de cómo fuesen las relaciones personales de cada uno de ellos con sus miembros. Así, las ausencias de varios vocales de la Comisión en una junta determinada obligó a veces a convocar a otro de ellos. De este modo ocurrió, por ejemplo, en la reunión del 10 de agosto de 1786, a la que Ignacio Tomás acudió para cubrir las faltas de Fernández, Machuca y Regalado. Cuatro miembros tan sólo asistieron a varias de ellas, como las del 24 de octubre y 9 de noviembre de ese mismo año. Quizá por este motivo en la junta particular del 3 de diciembre se tomó la determinación de agregar a la Comisión en calidad de vocales a los académicos de mérito Manuel Turrillo y Guillermo Casanova ${ }^{60}$. Diego de Ochoa se incorporó a la del 3 de mayo de 1787.

No obstante, los académicos de mérito conseguían algunas ventajas honoríficas y. sobre todo, hasta económicas por estas tareas interinas, pues muchas de las comisiones concedidas por el Consejo a través de este servicio para inspeccionar y realizar obras públicas, se adjudicaron durante este primer período a los asistentes a sus reuniones. Así, Ignacio de Tomás, Diego de Ochoa, Manuel Turrillo y Alfonso Regalado Rodríguez realizaron entre 1786 y 1787 numerosas comisiones para los lugares más dispares del Reino unas veces desde Madrid, sin tener que desplazarse; pero otras muchas más encargándose de inspeccionar las obras «in situ». Ello quizá se debiera a que los directores y tenientes directores no se pudieran ocupar de tal labor por tener que atender con tada prioridad a la docencia.

Pero el sistema de designación de los académicos de mérito integrantes de la Comisión, su número y duración resultaban demasiado vagos por indeterminados en la real orden fundacional. Ello podía ocasionar a!-

Actas del la junta particular del 6 de abril de 1786. AASF: $3 / 124$, fol. 10 anv.

Actas de la junta de la Comisión de arquitectura del 21 de diciembre de 1786. AASF $3 / 139$, fol. 48 anv. -50 anv. 
gunos problemas importantes a la Academia al establecerse una serie de derechos e intereses creados, que con el tiempo podrían dar lugar a reivindicaciones. Por tal motivo José Moreno, el primer vicesecretario entre 1786 y 1791, se preocupó de reglamentar muy políticamente los principales puntos conflictivos. Propuso a la junta particular del 6 de diciembre de 1789 por medio de una representación leida en ella, que los académicos de mérito, que no fuesen profesores, se alternaran en las juntas de dicha Comisión de arquitectura ${ }^{61}$. En su opinión los asistentes aprendían mucho al oír hablar en tales reuniones a los arquitectos más experimentados sobre la realización y censura de los proyectos arquitectónicos de obras públicas. Asimismo, añadía en su escrito que estos académicos tenían más trabajo que los de las otras dos Academias. Contraian, así, un mérito señalado con este centro madrileño de las Bellas Artes.

Moreno pensaba, que ambos aspectos tan positivos obligaban, a que tal honor de participar en esas juntas de la Comisión alcanzara también a los demás académicos de mérito. De esta forma se repartía tanto el trabajo como el beneficio consiguientes. Pero el vicesecretario iba aún más lejos en su raciocinio al demostrar una capacidad política bastante sutil: consideraba que la permanencia de algunos académicos de honor en esas reuniones, producia también un inconveniente bastante notable, al servir de precedente. Así, a la hora de cubrir las vacantes de tenencias de arquitectura, si la Comisión proponía a los individuos de asistencia continuada, tal y como era razonable, se vería quizá privada de promover a otros académicos de mérito, quienes, sin acudir a las juntas, podrían ser más dignos de ocupar las plazas. Por el contrario, en el caso de promocionar a estos últimos, aunque no hubieran estado presentes en las reuniones de la Comisión, los asistentes seguramente considerarían que de nada les había valido su quehacer. De esta forma se excusarían en el futuro para no ir a ellas o acudirían con desgana.

José Moreno propuso por tales motivos, que el nombramiento de los académicos de mérito para formar parte de la Comisión de arquitectura tuviese una periodicidad de uno o de dos años a lo sumo. Pensaba que con esa alternancia los beneficios y también las servidumbres alcanzarian a todos. De esta manera nadía podría alegar méritos, que obligaban a la Academia a la hora de realizar los nombramientos en perjuicio de otros aún más sobresalientes para el público y para este cuerpo académico.

Actas de la junta particular del 6 de diciembre de 1789. AASF: $3 / 124$, fol. 126 anv -127 rev. 
Al final de su escrito presentaba a la consideración de esa junta particular la idea de que, si la Academia aceptaba tales razones, se separasen de la Comisión a Turrillo y a Regalado, quienes habían servido en ella durante más de dos años. Para sustituirlos propuso una alternativa. En primer lugar que se nombrara a los académicos de mérito más antiguos: Ignacio Tomás, Pedro Garcia y Pablo Morales. Pensaba que de esta forma se calmarían los resentimientos, que pudieran tener, al ver que se habia nombrado anteriormente a otros arquitectos en posesión de unos títulos obtenidos diez años después que ellos. Pero, al mismo tiempo, daba los nombres de Ramón Durán, Ramón Alonso y Antonio López Aguado en calidad de alternativa, al considerarles como jóvenes con mucho futuro.

La junta particular debió debatir durante bastante tiempo las ideas de José Moreno en esta reunión del 6 de diciembre de 1789; pero no llegó a ninguna conclusión positiva. Así, no se decidió ni sobre el tiempo que el nombramiento debía durar ni acerca del número de académicos de mérito, que acudirian a las reuniones de la Comisión, ni tampoco sobre quiénes debian ser designados para reemplazar a los antiguos.

El vicesecretario insistió con otro escrito posterior sobre este mismo asunto, que parecia preocuparle bastante. Su carta se leyó en la junta particular siguiente del 3 de enero de $1790^{62}$. En esta ocasión José Moreno se manifestó, después de reflexionar bastante astutamente con el pensamiento quizá puesto en el desaire que Manuel Turrillo y Alfonso Regalado podrian sentir al conocer sus sustituciones respectivas en las juntas de la Comisión. Indicó que este último debía establecerse en Córdoba por dotación concedida por el Prelado de la ciudad, motivo por el cual no acudiría en adelante a las reuniones. Propuso que se nombrase a Turrillo para otro año con el fin de no desairarle junto con Ignacio Tomás, quien había concurrido a las reuniones durante algún tiempo por orden del difunto viceprotector ${ }^{63}$. Pero al mismo tiempo también se designarían por dos años a Pablo Morales, al ser el individuo más antiguo en este cuerpo de académicos de mérito, y a Ramón Durán, al haber sido el primero examinado según las reales órdenes vigentes. Promovía, además, la

\footnotetext{
Actas de la junta particular del 3 de enero de 1790. A.A.S.F.: $3 / 124$, fol. 129.

5. Oficio de Antonio Ponz, secretario de la Academia, dirigido a José Moreno, vicesecretario y de la Comisión de arquiectura, dándole cuenta de lo acordado en la junta particular del 3 de enero. Se le notifica la continuidad en esas juntas de los académicos Manuel Turrillo e lgnacio Tomás y los nombramientos por dos años de Pablo Morales y Ramón Durán. Madrid, 7 de enero de 1790. Actas de la junta de la Comisión de arquitectura del 15 de enero de 1970. A.A.S.F:: $3 / 139$, fol. 134.
} 
idea de que, al salir al año siguiente Turrillo e Ignacio Tomás, estos dos últimos quedasen en calidad de miembros más antiguos en esas juntas. Se podría nombrar de este modo a otros dos académicos de mérito. $Y$ este sistema rotativo se seguiría en el futuro.

Así, si se seguía la hábil propuesta de José Moreno, propiciada indudablemente por la muy oportuna salida de Regalado de la Corte, se establecería un turno bienal al tiempo que acudirían cuatro académicos de mérito a tales reuniones de la Comisión de Arquitectura, elegidos de entre los individuos más antiguos en posesión de este grado, y también, y al mismo tiempo, de entre los más recientes. Con ellos había a la par la experiencia y la juventud tan necesarias. Además, nadie adquiriría de tal forma con el paso de los años ni más beneficios a la hora de realizar los nuevos nombramientos en la Academia ni más cargas siempre gravosas que los demás. Por último, se limaban asperezas y resentimientos pasados, y se prevenía una serie de medidas, que las quitarían en el futuro. Todo lo cual agradó a la junta particular del 3 de enero de 1790, que, complaciéndose, sin duda, con las ideas de José Moreno - no podía ser de otra forma dada su gran habilidad política-, acordó llevar a efecto la propuesta del vicesecretario, tal y como se realizó.

Tal vez también podría pensarse que José Moreno buscaba consciente $o$ inconscientemente con estas medidas otros efectos secundarios igualmente muy importantes tanto para la vida académica como para las juntas de esa Comisión, que no indicaba en sus escritos. Resultaría posible que de este modo deseara establecer un equilibrio estable dentro de una escala jerárquica en el número de los componentes entre los cuatro profesores - dos directores y dos tenientes directores - y los otros tantos académicos de mérito incorporados en la Comisión. Éstos cubririan en su calidad de interinos por dos años y sin generar ningún gasto las ausencias de aquéllos, los estables, formándose en tales reuniones como una alternativa futura para cubrir sus puestos en la labor censoria. Tal función no era novedosa: en las labores docentes los académicos de mérito suplían a los profesores en sus ausencias, considerando esta tarea como un honor prestigioso.

Pero al mismo tiempo el vicesecretario hallaría otro equilibrio, que tal vez podría aún más proporcionar la fuerza necesaria a sus decisiones de árbitro como secretario de esas reuniones. Si había disparidad de criterios en los juicios dados sobre los proyectos presentados de obras públicas. estaría en condiciones de encontrar alianzas o en uno o en otro estamentos, inclinándose por cada uno de ellos según los intereses de la Academia o incluso los propios. Éstos a su vez se dividian respectiva- 
mente en dos: por un lado los directores y tenientes directores, el cuerpo docente jerarquizado, y por el otro los académicos de mérito antiguos y nuevos incorporados a la Comisión.

La existencia de ocho miembros en estas juntas, cuatro de ellos fijos y otros tantos interinos, daba también la posibilidad de hallar entre ellos y de hacer participar a las diversas escuelas de arquitectos existentes en la Academia. Así, la formación de cada uno en esta disparidad de tendencias de tan distintas filiaciones con el común interés académico por el triunfo del nuevo clasicismo, que era su fuerza, proporcionaría la diversidad tan necesaria dentro de esa misma unidad y daba del mismo modo la posibilidad de no caer en arbitrariedades formales a la hora de juzgar los proyectos remitidos desde distintas regiones del Reino.

En efecto, un año después, el 2 de diciembre de 1790, José Moreno remitió un oficio a Antonio Ponz, cuyo contenido fue tratado en la junta particular del día 5 de ese mismo mes ${ }^{64}$. Proponía en él a los académicos de mérito Ignacio Haan y a Ramón Alonso, para que asistiesen desde principios de 1791 a las juntas de la Comisión de arquitectura en lugar de Manuel Turrillo y Alfonso Regalado, pues debian cesar en virtud de aquel acuerdo. Exponía para su designación que tanto el uno como el otro eran "buenas prendas" y "de los más antiguos y más propios por sus escuelas, para que hubiera profesores de todas en la Comisión y se evitasen aún las apariencias de parcialidades» 65 .

José Moreno daba muestras de esta forma, una vez más, de su habilidad política, al desear que en esas juntas de arquitectura participaran arquitectos de distintas escuelas y talantes. Tal y como lo demostraba también el haber ido, precisamente durante esas fechas y en calidad de su empleo de vicesecretario, a El Escorial a dar al protector los ejemplares de la Relación de Premios de ese año de 1790, para que los entregase al Rey y a su real familia ${ }^{66}$. Pero al mismo tiempo había cumplido con los individuos académicos y otros principales Señores de la Corte, que residian en este Real Sitio. Las anécdotas a veces son bien significativas.

No resulta extraño, así pues, que José Moreno fuera designado por la real orden del 3 de enero de 1791 secretario de la Real Academia de Bellas Artes de San Fernando, sustituyendo a una personalidad tan des-

\footnotetext{
64 Actas de la junta particular del 5 de diciembre de 1790 . A.A.S.F.: 3/124, fol. 149 rev. 150 anv.

55 El oficio de José Moreno a Antonio Ponz, fechado el 2 de diciembre de 1790 se halla en A.A.S.F.: Leg.: 28-1/1. La respuesta del secretario de la Academia está datada el 5 de diciembre. 66 loidem, fol. 150 anv.
} 
tacada por su erudición y habilidad política como era Antonio Ponz. Dos grandes méritos hay que atribuir al abate: la promulgación de las reales cédulas de 1777 y la creación de la Comisión de arquitectura en 1786. Su sucesor, que le había ayudado y suplido en sus tareas administrativas, era un hombre plenamente formado e integrado en la Academia, a la que conocía maravillosamente y con la que comulgaba a la perfección. Por su empleo de vicesecretario durante cuatro años y por el puesto de conserje de su padre, se movía muy bien entre todos los entramados burocráticos de este centro, que eran realmente muchos y bastante complejos.

Pero la junta particular del 6 de febrero de 1791 pensaba que se debía designar a otro individuo para que cubriese el empleo de vicesecretario, que creía vacante al ocupar Moreno el superior de secretario general de la Academia ${ }^{67}$. El tema fue debatido ampliamente, indicándose varias consideraciones en su transcurso por los consiliarios, debido al "pulso que ésta" - se refiera a la junta- "debía de proceder en una elección de tanta consecuencia para el beneficio público y el honor del Cuerpo que presta su nombre a las aprobaciones y censuras de la Comisión».

Se pensaba que tal empleo exigía una "más que mediana inteligencia de la arquitectura para extraer con acierto los expedientes de obras públicas, de que aquella junta conoce, y para extender con propiedad los informes". A lo que se añadía que, además, era preciso práctica en los negocios, tesón, eficacia, sagacidad - he aquí una de las capacidades demostradas por Moreno-, y uotros que se hacen no menos esenciales para la comunicación de oficio con todos los Tribunales y personas más autorizadas el Reino". Era también necesario observar la imparcialidad más rigurosa en los dictámenes, aliviar a los miembros de la Comisión, que aguantaban un gran trabajo sin recompensa alguna en "obsequio de la causa común y de la Academia». Debian distinguir, asimismo, entre la utilidad real de muchas obras y los fines particulares de los artífices, que las proponían.

Todas estas cualidades, que debian ser reunidas por un vicesecretaric, las redactó el propio José Moreno en las actas de esta junta particular. Demuestran, es verdad, la vanidad realista del personaje, quien quiso dejar presente en ellas un halago bien implícitamente explícito de sus condiciones personales. Pero, además, quería demostrar, por si existía alguna duda, que él era la única persona de la Academia, que poseía tales dones. Expresaba a las claras sus deseos de continuar sir- 
viéndola en su doble empleo de secretario y de vicesecretario. A todo ello había que añadir su condición de segundo director de matemáticas, quien realmente daba las clases, pues Bails se dedicaba a redactar los libros, y de hijo del conserje de la Academia. Es muy posible que nadie en este centro acaparara tantos empleos y tan activos e importantes como José Moreno en la historia de este organismo, al que se consideraba tan integrado.

Moreno tuvo que abandonar sus clases de matemáticas, pues sus muchas ocupaciones le impedian dedicarse a la docencia. Tampoco debía parecer bien, que tuviera tantos empleos. Dejó libre, así, su plaza de director segundo de este ramo, puesto al que Pedro García, académico de mérito, pretendió en un memorial, que fue leído en la junta particular del 13 de marzo de $179^{68}$. No obstante, el propio secretario echó por tierra su aspiración al considerar como persona más idónea para tan importante enseñanza a Antonio de Varas y Portillo, clérigo pensionado por el Rey, y para servir de sustituto. Este personaje había realizado estudios de matemáticas y literatura, y tenia, además, la circunstancia de haber sido discípulo de la misma Academia. La junta particular del 7 de noviembre de 1790 había aceptado la propuesta de Moreno de nombrarle para que le reemplazase en sus clases. Éste consideraba que tenía "las prendas propias de un buen Maestro" y la experiencia necesaria, pues también había sido sustituto de una de las cátedras de los Estudios Reales de San Isidro. Los consiliarios aceptaron su proposición. Quizá, si hubieran leído en el futuro y adivinado el papel de promotor de disturbios entre los matemáticos y los arquitectos en 1792, no le habrian designado para ocupar tal empleo, que recayó en él el 23 de marzo por nombramiento del Conde de Floridablanca ${ }^{69}$.

La junta particular no halló, así pues, en febrero de 1791 persona para proponer al Rey con total confianza, que reuniese todas estas importantes condiciones, con el fin de desempeñar ese puesto de la secretaría de la Comisión de arquitectura. Por tal motivo decidió atender la oferta de José Moreno, llevado de su agradecimiento y del deseo de servir a este centro, de simultanear en su persona ambos empleos hasta que el Rey decidiera otra cosa diferente a propuesta de la misma Academia. Esta resolución fue comunicada al protector el 21 de febrero de 1791, quien aceptó todos sus términos «para no apresurar la elección de secretario de la junta de

\footnotetext{
Sie Actas dela junta particular del 13 de marzo de 1791. A.A.S.F.: 3/124, fol. 158 rev. -159

6. El oficio nombrando a Antonio de Varas segundo director de matemáticas se leyó en la junta particular del 3 de abril de 1791. A.A.S.F.: 3/124, fol. 161.
} 
Comisión» ${ }^{70}$. Al mismo tiempo agradecía a José Moreno este trabajo y su celo de no "perdonar fatiga alguna en beneficio de las Artes".

La constitución física de José Moreno quizá no fuera capaz de asumir tanta laboriosidad como desde entonces se exigió a sí mismo al ocupar al mismo tiempo ambos empleos tan trabajosos y que obligaban a desarrollar tanta atención, capacidad y fortaleza corporal y mental. El caso es que sólo sobrevivió un año a tal carga, falleciendo el 5 de enero de 1792. Un par de días antes, por real orden fechada el 3 de ese mismo mes, le fueron concedidos los honores de secretario de S. M. con el beneficio de que se le relevara del pago de la media anata. Ignacio de Hermosilla desde el 1 de marzo de 1760 y Antonio Ponz el 1 de septiembre de 1776 habían obtenido antes que él este beneficio, que parecía concederse siempre al empleo de secretario de la Academia. Después isidoro Bosarte lo obtuvo el 17 de febrero de 1793, aunque en la real orden firmada por Manuel Godoy, Duque de Alcudia, se indicaba que en lo sucesivo no se daría este honor a los secretarios de ese centro, pues se concedía a la persona y no al empleo ${ }^{71}$.

Pero pocos días antes en la junta particular del 18 de diciembre de 1791 de nuevo se realizó la alternativa de los académicos de mérito en las reuniones de la Comisión de arquitectura. Esta vez salieron Pablo Morales y Ramón Durán, que habían permanecido en tales juntas durante dos años. Mateo Medina y José de Toraya fueron nombrados para sustituirles en las respectivas vacantes ${ }^{72}$.

\section{LOS ARQUITECTOS DE PROVINCIAS Y LA COMISIÓN DE ARQUITECTURA}

El control de las obras públicas no era posible sin que la Academia, además de disponer de una legislación adecuada y de ese núcleo de profesores censores, contara con los arquitectos y maestros de obras aprobados por ella - muchos de los cuales se habían formado en sus Salas o se habian examinado con ellos-, que residian en las distintas ciudades del Reino. Eran personas de su entera confianza, teórica y legalmente ca-

La resolución del protector Conde de Floridablanca confirmando la continuidad de José Moreno como vicesecretario, datada en Palacio el 28 de febrero de 1791, se leyó en la junta particular del 13 de marzo de ese año. A.A.S.F.: 3/124, fol. 157 rev.

Académicos. Secretarios. Siglo xviit. A.A.S.F.: Leg: : 39-7/1

Actas de la junta particular del 18 de diciembre de 1791 . A.A.S.F.: $3 / 124$, fol. 181 rev. -182 anv. 
pacitadas para realizar los proyectos arquitectónicos que se les encomendasen; pero también dispuestas a denunciar a este organismo cuantas obras públicas de consideración se realizasen en sus urbes y en las localidades próximas sin el permiso legal de la Academia y por maestros gremiales. El juego de los intereses comunes propiciaba esta actitud, pues los arquitectos de provincias eran los más interesados en que se cumplieran las disposiciones académicas para disponer de más trabajo, que en ocasiones conseguian de este centro de las Bellas Artes.

Con el paso del tiempo, y según la Academia iba formando y aprobando profesionales de la arquitectura, se fue entretejiendo una auténtica tela de araña a su servicio por la geografía española. En 1785 se hallaban en provincias treinta y cinco arquitectos aprobados por el instituto. Al crearse en 1786 la Comisión ya se contaba con un grupo de arquitectos y de maestros de obras cualificados. Desde 1802 se encargó de imprimir anualmente una lista de los maestros arquitectos y maestros de obras aprobados para tenerla en consideración a la hora de aprobar o reprobar proyectos ${ }^{73}$. El instituto de las Bellas Artes les protegía; pero de la misma forma se valía de ellos para realizar todos y cada uno de sus objetivos. El "gremio académico» debía sustituir a los gremios profesionales, y centralizar y censurar desde la Corte cuantos proyectos se realizasen en España.

En Galicia la Academia dispuso de profesionales de su confianza como Miguel Ferro Caaveyro, Melchor Prado y Mariño en Santiago de Compostela, Fernando Domínguez y Romay en La Coruña, y Francisco Martínez Vidal. En Castilla se hallaban en Burgos, Fernando González de Lara y León Antón Díez; en Salamanca, Juan de Sagarvinaga; en Valladolid, Francisco Álvarez de Benavides y Lesmes Gabilán; en León, Sánchez Pertejo. En La Rioja trabajó Diego Ochoa. En Aragón actuaron Agustín Sanz y José Francisco Rodrigo. En Murcia, Salvador Gozálvez Ros y Bartolomé Ribelles, quien residía en Valencia. En Andalucía, en Granada coincidieron Domingo de Tomás, director desde 1786 de la Escuela de Dibujo de esta ciudad, y Francisco Quintillán y Lois; en las Nuevas Poblaciones trabajaba Antonio Losada; José Rodríguez Díaz estaba en La Carraca, Cádiz... Esta simple enumeración de algunos de los más destacados arquitectos académicos de provincias proporciona una idea bastante apropiada de cómo la Academia madrileña extendió sus influencias por toda España.

Actas de la junta ordinaria del 7 de marzo de 1802. AASF: $3 / 86$, fol. 178 
Sin embargo, el problema surgió al percatarse los arquitectos académicos de provincias de que ellos eran quienes sufrian las correcciones continuas de los profesores de la Comisión en sus propios proyectos de obras públicas, pues numerosos practicantes gremiales seguían construyendo a su antojo sin remitir a la Academia los diseños previos. Ello les desacreditaba ante los ojos de los mecenas, quienes preferían a los maestros gremiales por librarse del férreo control académico. Así, en 1800 se decidió por medio de una circular de Silvestre Pérez remitida por Isidoro Bosarte, como secretario, a todos los académicos de mérito, maestros arquitectos y maestros de obras, que en adelante enviaran a la Comisión particular y' confidencialmente los borradores de los proyectos de obras públicas antes que los planes ya definitivos ${ }^{74}$. En ellos se harían en caso de necesidad las enmiendas o advertencias correspondientes, que parecieran oportunas para la mayor regularidad de los edificios. Se quería evitar la publicidad de tales correcciones. Las censuras habian producido muchos resentimientos particulares y quejas al enterarse de ellas los organismos y personas, que habian encargado los diseños.

Hay un hecho interesante que destacar aquí. Algunos de los académicos de provincias se habian formado en la Academia madrileña como discípulos; pero otros simplemente se examinaban en ella de sus conocimientos para practicar después la profesión de una forma legal en su tierra natal. Lo importante es. que en sus lugares de residencia se dedicaban a preparar a su vez a otros facultativos de la arquitectura, quienes después acudian a Madrid a pasar las pruebas correspondientes con certificados de haber practicado con ellos. Legalizaban, así, sus estudios. Había, por lo tanto, una enseñanza híbrida entre el antiguo taller y la Academia, que controlaba esos conocimientos y expedía los títulos correspondientes. Pero, además, se formaron auténticas escuelas locales dependientes de un maestro con signos de identidad propios, que daba cierta tradición. El instituto madrileño de las Bellas Artes no podía pedir que se estudiase en ella; pero exigía una cultura arquitectónica dentro del sistema académico y practicaba un control. Esto ocurrió, sobre todo, durante la primera mitad del siglo $x \mid x^{75}$

\footnotetext{
La minuta de la circular en AASF:28-1/2. También hay una relación de arquitectos a quienes se envió y la contestación de éstos. Sobre este asunto se dedica un epigrafe en Garcia Mılı no, J. E. Arquitectura y burocracia..., págs. 339-347.

Sobre la preparación de los arquitectos decimonónicos en provincias y su examen en las Academias puede verse la tesis doctoral de BALSAlobre GaRcia, J. Ma., "La imagen académica del teatro español decimonónico. El Teatro y su censura en la Real Academia de Bellas Artes de San Fernando (1800-1870)". Tesis doctoral dirigida por J. E. Ga Melero. Madrid, UNED, 1997, pág. 396.
} 


\section{LOS ARQUITECTOS ITINERANTES}

Con mucha frecuencia la Academia nombró a determinados arquitectos para que realizaran el reconocimiento de las obras «in situ», lo cual provocaría la crítica de Juan de Villanueva en 1792 por pensar que suponía un gasto excesivo para este instituto. Los miembros de la Comisión se consideraban a veces incapaces de dictaminar sobre tales proyectos sin que un profesional de su entera confianza viera y estudiase antes el lugar en donde el proyecto se construiría o el estado de realización de una obra pública. Se solía designar en estas juntas a los arquitectos académicos de mérito domiciliados en las mismas ciudades o en lugares próximos a ella, - se nombraba a quien en ese momento viajaba por la región con la misión de supervisar otro encargo para economizar gastos.

En algunas ocasiones la Comisión enviaba a uno de sus miembros, establecido en la Corte, para realizar la inspección. Entonces se aprovechaba, si era necesario, su salida con la finalidad de que estudiase varias construcciones establecidas en la misma zona, realizando, así, auténticos itinerarios con paradas en distintas localidades más o menos próximas entre sí.

Pero a veces los escribanos de Cámara por petición de las autoridades de las villas hacian a la Academia contraproposiciones, para que en lugar del arquitecto académico designado por este instituto fuera otro, que se hallaba más próximo al sitio, a donde tenía que desplazarse para hacer una inspección sobre el terreno. Se deseaba reducir los gastos ocasionados por tales traslados, que solían correr a cargo de dichas localidades. De este modo sucedió, por ejemplo, en la junta de la Comisión de arquitectura del 28 de julio de $1786^{76}$. La villa de Torquera solicitó que en lugar de Alfonso Regalado Rodríguez acudiera a esta localidad Mateo López, que se hallaba a tan solo cinco leguas, con el fin de informar a la Academia sobre el sitio, el pensamiento y el costo de un puente.

Manuel Machuca y Vargas fue uno de los arquitectos de la Academia más viajeros y que recibió un mayor número de encargos para idear nuevas fábricas durante este periodo de 1786 a 1792. El 4 de mayo de 1786 se le propuso para que realizara varias reconocimientos, como el de un puente sobre el río Lalandiga, en el lugar de Berrocal, obispado de Salamanca. Como alternativa suya se dio el nombre de Diego de Ochoa,

Acta de la junta de la Comisión de arquitectura del 28 de julio de 1786 . AASF: $3 / 139$, tol. 
quien se hallaba en otra comisión en la villa de Castro Gonzalo, que estaba relativamente cercana ${ }^{77}$.

Pero en la misma junta, se había acordado proponer al Consejo a Machuca para idear la fábrica de la colegiata de la villa de Ribadeo con el decoro y el arreglo necesarios ${ }^{78}$. También en esa misma reunión del 21 de abril de 1786 se rechazó al considerarla defectuosa la obra realizada por Julián Armero en la iglesia parroquial de la villa de Miedes según los diseños del maestro Juan Manuel de la Quadra. Manuel Machuca había hecho los reconocimientos, una declaración y tres dibujos de ella, que fueron aprobados por la Comisión, porque su pensamiento era «juicioso y arreglado", juzgándose la fábrica construida por Armero como "poco sólida" al considerarse también que era arriesgado cerrar la iglesia sobre ella, y los mismos dibujos de la Quadra como de "mala forma" ${ }^{79}$.

\section{SILVESTRE PÉREZ Y LOS ESTUDIOS DE ARQUITECTURA DE LA ACADEMIA EN 1799}

Se conserva en el archivo de la Real Academia de Bellas Artes de San Fernando el borrador de un dictamen escrito por Silvestre Pérez, fechado el 8 de abril de 1799, a los pocos días de haber accedido al empleo de vicesecretario el 10 de marzo, para arreglar los estudios de este centro en la rama de la arquitectura civil con motivo del nuevo plan, que el viceprotector Marqués de la Espeja deseaba establecer. Estructuró su método en dos partes distintas de una forma sistemática y progresiva: la primera de ellas dedicada al parecer, pues no lo indica en el texto, a los estudios generales, y la segunda a los específicos de la arquitectura ${ }^{80}$.

Los arquitectos debieron reunirse ese mismo día, partiendo de un acuerdo general ${ }^{81}$. Casanova, Francisco Sánchez, Manuel Martín Rodríguez y Machuca enviaron también sus dictámenes. El de Sánchez era el mismo escrito, ligeramente modificado, del 14 de octubre de 1792. Machuca consideraba imprescindible la formación de una "Biblioteca completa para el uso de los Profesores y Discípulos", asi como subscribirse a

Ibidem, 4 de mayo de 1786 , fol. 35 anv. Ibidem, 4 de mayo de 1786, fol. 35 rev.. lbidem. 21 de abril de 1786, fol. 34 anv.

80 El dictamen de Silvestre Pérez, fechado en Madrid el 8 de abril de 1799, en AASF: leg.: 18 2/1. El manuscrito es de nueve folios. En el legajo 18-4/ 1 se conserva el plan de estudios de 1799 con fecha 24 de abril de 1799. Incluye pintura, escultura y arquitectura.

Planes de estudio. Acuerdos. Reunión del 8 de abril de 1799. AASF: leg.: 18/8-8 


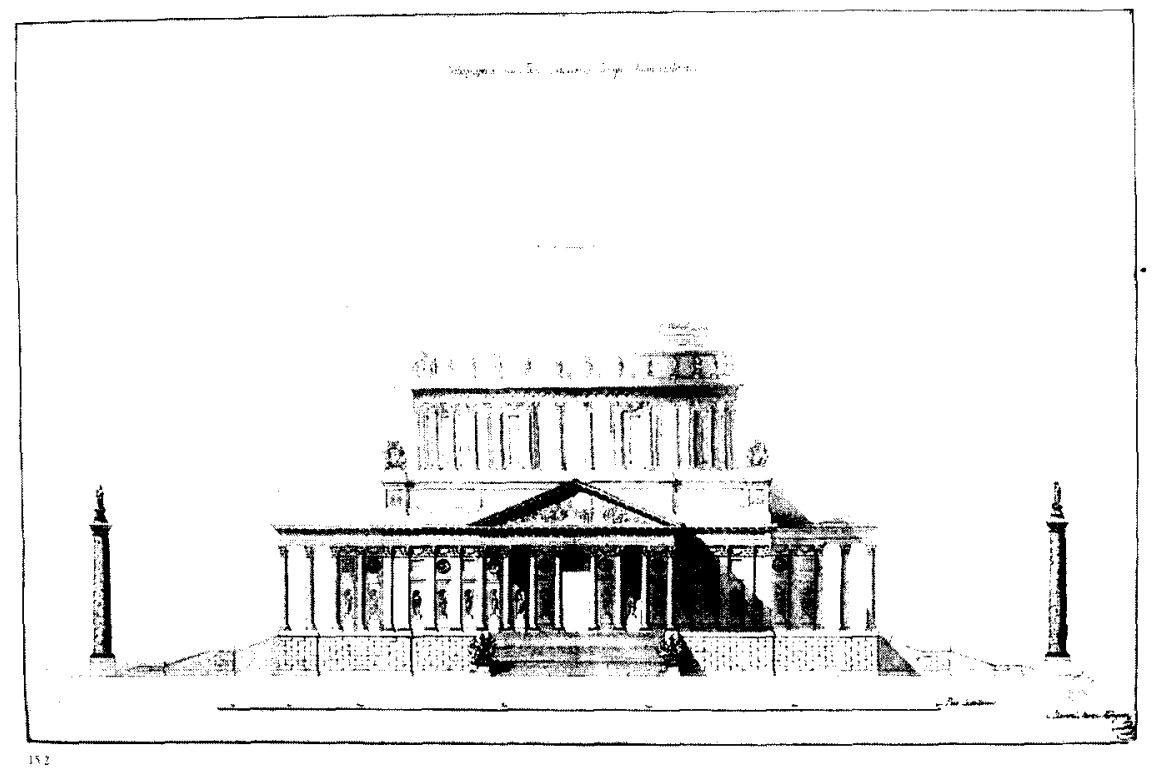

Lám. VIII: Juan Pedro Arnal : L'elevation del templo. 1763.

"todas las memorias y disertaciones que fuesen saliendo a luz en Italia, Francia, Inglaterra, etc.» ${ }^{82}$. Manuel Martín Rodríguez, muy pragmático era partidario de la colocación de modelos para que los alumnos conocieran antes de diseñar las distintas partes de la arquitectura: arcos, bóvedas, cimbras, armaduras, máquinas hidráulicas, capiteles, basas de columnas y pilastras de todos los ordenes y trozos de cornisamentos ${ }^{83}$. Por su parte, Pedro Arnal fue el último en exponer su opinión, habiéndose ya leído las de sus compañeros (lám. VIII). Ello le permitió puntualizar algunas de las ideas de aquéllos, pero sin profundizar en ellas, como si no diese a sus juicios personales una auténtica transcendencia. Así, por ejemplo, a la propuesta de Machuca sobre la adquisición de obras extranjeras de arquitectura, pensaba que era precisa su traducción al español. Por su parte creía conveniente que en la sala de principios de arquitectura hubiera un estudio completo de los tres órdenes griegos, "con arreglo a la serie cronológica de los tiempos de sus perfecciones y decadencia, para que por este estudio todos los que se dedicasen a este Arte, lo aprendiesen desde su pri-

\footnotetext{
8. "Méthodo de Enseñanza de la Arquitectura, que propone a la presente Junta Artistica, el Profesor Machuca». Buen Retiro, 14 de abril de 1799. AASF: leg.: 18-2/1.

8.3 Dictamen del Sor. Rodríguez, Arquitecto. Madrid, 16 de abril de 1799. AASF: leg.: 18-2/1.
} 
mitivo origen hasta el día, pues los que se dedican a una Ciencia, sino saben cómo tuvo su origen, y cuáles fueron sus progresos, su decadencia y su restauración, mal podrán dar razón a fondo y como corresponde de ella, y me parece que quien no estudie bajo estos principios y reglas, nunca podrá llegar a perfeccionarse en su Arte ${ }^{84}$. Ignoró totalmente lo escrito por Silvestre Pérez, pues no alude a él.

El vicesecretario expuso su opinión sobre los estudios generales en nueve puntos, aunque en realidad son ocho, pues tachó el primero de ellos sin correr la numeración. Se corresponden en resumen con el aprendizaje del dibujo, de la cultura histórica y de las matemáticas. Siguiendo la escuela tradicional de la Academia, que daba una gran importancia al dibujo para el futuro arquitecto, inició el programa con la adquisición de conocimientos del diseño de las figuras geométricas, pero sin hacer uso ni de la regla ni del compás, instrumentos que tan sólo admitía como útiles para conocer los defectos y corregirlos. Pensaba que de esta forma los niños adquiririan "aquella exactitud de vista, que es la base fundamental del diseño", mientras el ojo todavía no se ha formado. Después copiarían las partes del cuerpo humano y a continuación la figura entera "por originales hechos a cuadraturas", también sin el empleo de tales instrumentos. Pasado algún tiempo empezarían a dibujar hasta que supiesen contornear una figura y saberla manchar con alguna diligencia y propiedad de claroscuro. Para lograrlo se valdrían del lápiz, la tinta china u otro color oportuno.

Silvestre Pérez propuso en su plan de estudios que al mismo tiempo que los discípulos aprendían el diseño y el dibujo, el lenguaje y la forma de expresión del arquitecto según la opinión de los profesores de arquitectura encabezados por Juan de Villanueva en su contestación de 1793 a la crítica del matemático Antonio de Varas, leerían la historia antigua y moderna, sobre todo la de las bellas artes y, en especial, de la arquitectura, y unos principios de la geografía. De esta manera manifestaba su historicismo y humarismo, una de las bases más importantes y firmes de su formación como arquitecto y de su misma práctica arquitectónica.

Luego que los discípulos hubiesen cursado tales estudios, deberían aprender los principios de las matemáticas con aplicación a la arquitectura durante dos años, que convendría repitieran al no ser "ácil, por mucho talento que tuvieran los Jóvenes, que se impongan en dos años

B4 El dictamen del director Pedro Arnal está fechado en Madrid, el 21 de abril de 1799. AASF $\operatorname{leg}:$ : 18-2/1. 
en este Estudio tan importante». Pero, adhiriéndose de nuevo a las ideas de Juan de Villanueva y de los demás arquitectos manifiestas en 1792 , afirmaba que entre tanto no debian dejar de dibujar dos horas por la noche. A continuación cursarian la física experimental, estudio que calificaba de muy necesario para las artes; pero siempre, volvía a insistir, aplicándose al dibujo en horas nocturnas. Después abordarian el aprendizaje de la perspectiva, que ya se había facilitado en cierta medida a los alumnos por medio del estudio anterior de las superficies y de los sólidos en las matemáticas, y de la óptica a través de la física. A lo que añadía en su programa: "y así convendría que la estudiasen antes que la arquitectura porque, si se ha de enseñar científicamente desde su origen, sabiendo de antemano la perspectiva comprenderán con más facilidad las demostraciones".

Una vez realizados estos estudios de carácter general o introductorios, cuya principal base se halla en el aprendizaje primero del dibujo y después de las matemáticas, el discípulo debería presentar las certificaciones de los respectivos directores para pasar a cursar a continuación los propios de la arquitectura. Se seguía, así, la solución ecléctica y conciliadora entre ambas disciplinas asumida por la Academia en el debate de 1793 entre los arquitectos y el matemático Antonio de Varas, quien en 1792 había propuesto una formación plenamente científica del arquitecto, quitando tanto protagonismo al dibujo. Silvestre Pérez los estructuró en doce puntos progresivos y complementarios entre sí. Tratan tanto de la formación del alumno, la auténtica finalidad de este dictamen, como de los medios complementarios que los profesores debían poner para conseguir una enseñanza mejor y también de la obtención del título de académico de mérito.

El aprendizaje de la arquitectura tendría una base práctica. El profesor daría lecciones científicas sobre esta disciplina y "tantearía" al discípulo, quien debería llevar al otro día delineado el asunto explicado en esa jornada. Le advertiría de los defectos, en que hubiese «incurrido, tanto en inteligencia como de delineación y de sombras". Las "sombras» siempre preocuparon en estos años finales de la llustración.

Pero la base teórica de esta enseñanza la proporcionaba, no podía ser de otra forma en este medio académico y en tal época, el siempre imprescindible tratado de Vitruvio. Y para conocer la arquitectura clásica había que partir del aprendizaje de los tres ordenes primitivos griegos, estudiados primero en general y después de una forma particular en todas sus partes, explicando "el carácter de cada uno, su historia, distinguiendo lo esencial puro de ellos, y lo que para darles más elegancia y unir sus partes, las aumentaron los mejores arquitectos antiguos». Pero también 
era preciso enseñar al discípulo los errores en el empleo de lo "superfluo", defecto en los que los arquitectos modernos habian incurrido, al intentar enriquecerlo.

Con la finalidad de profundizar en dicho conocimiento de los ordenes griegos se requería explicar a continuación la función -el "oficio» en definición de Pérez-y el uso de las distintas formas de molduras, basas, arquitrabe y cornisas. El profesor también introduciría al discípulo en los diversos motivos, por los cuales estos elementos variaban de tamaño unos y otros entre si y "las diferentes aplicaciones de las mismas según lo exijan las circunstancias». Pero al mismo tiempo que se les daba tal enseñanza más o menos teórica deberían dibujar por la noche el ornato de las molduras por modelos antiguos.

Después se explicaría las distintas proporciones dadas a los ordenes por los diferentes arquitectos a lo largo de la historia de la arquitectura, como, por ejemplo, Vitruvio y Palladio citados aquí por Pérez debido a su calidad de magistrales, enseñándoles sus métodos respectivos. Se compararían los unos con los otros y se confrontarian con los ejemplares antiguos conservados y con la "filosofía que dicta la sana razón". Pero al mismo tiempo los alumnos deberían dedicarse a la lectura de un «buen libro, que dicte algunas reglas de sencillez, de unidad y de decoro, tan necesarias para formar el buen gusto en todas las artes: y que enseñe también la buena crítica". Todo lo cual parece dar una idea bastante clara del racionalismo ecléctico, historicista y arqueológico dentro del más puro código clásico vitruviano de Silvestre Pérez, quien debía haber realizado tales estudios y ejercicios durante su pensión en Roma.

Silvestre Pérez dedicó el capítulo siguiente de este plan de estudios progresivo y racionalista al aprendizaje teórico-práctico de las proporciones aplicadas a los edificios en general y en particular a sus diversas tipologías. Enseñanzas que los alumnos debían practicar formando diseños, describiéndolos y haciendo la crítica de los proyectos realizados por otros con el pensamiento siempre puesto en los modelos de la Antigüedad. A lo cual seguirian las reglas generales de la distribución, advirtiéndose el "dilatado campo que ofrece la Geometria para variar las formas de las plantas en los edificios, sin olvidar los ejemplares antiguos».

Con una visión práctica puesta en su época, Silvestre Pérez pretendía que los futuros arquitectos conocieran bien la jurisprudencia aplicada a la arquitectura. Así, consideró necesaria la lectura de las Ordenanzas Municipales de la Corte, de las capitales de provincias y también de las extranjeras, si se podian hallar. Aspecto tan necesario en la formación de esta profesión como también el del conocimiento de aquella parte de la 
historia natural, que enseña la naturaleza y las propiedades de los materiales empleados en las obras.

Los discípulos partían, asi pues, del conocimiento teórico y de la aplicación práctica en los diseños de las reglas vitruvianas de unidad, sencillez y decoro, así como de las de comodidad y solidez, que conjuntamente constituían la belleza de la arquitectura. Pero también debian saber diseñar perfectamente la planta y los alzados de los distintos edificios, aspecto siempre imprescindible para pasar después, por último, a su ejecución. Este asunto se enseñaría en sala distinta y cpor medio de modelos de edificios hechos a propósito de numerosas partes separadas, y de cortes de cantería, de modo que puedan combinarse para estudiar la práctica, sin que escaseen las máquinas necesarias para aplicar las reglas de la Mecánica».

Pero Silvestre Pérez quiso ser pragmático en su dictamen. Pensaba que ninguno de estos estudios servirian para que se formasen buenos artífices, si no se les proporcionaba también los medios necesarios para ejercitar sus talentos y los conocimientos adquiridos durante sus estudios. Por esta causa quería que para que los arquitectos, así formados, dieran "todo el fruto a que la Patria es acreedora, sin ningún dispendio", se les fuera acomodando, tal vez un tanto utópicamente, por oposición en cada catedral después de haber obtenido el grado de académicos de mérito. Pero, siendo muy selectivo, pensaba que tal título no se daría a todos los profesores sólo por haber hecho su carrera metódica, sino tan sólo a aquellos arquitectos reconocidos por «beneméritos» después de haber hecho sus ejercicios, tal y como se practica entonces (lám. |X).

Recomendó, finalmente, que los directores de arquitectura se propusieran redactar por lecciones un tratado de principios de esta profesión sin láminas. Mientras esta obra se escribia e imprimía, se podría enseñar provisionalmente por el que tenía publicado la Academia, que era el de Benito Bails. Demostraba, así, su disconformidad, tal y como Pedro Arnal hiciera en su informe, con el libro elaborado eclécticamente, entresacando textos de diferentes autores y haciendo en realidad una antología admitida por la Academia, del antiguo director de matemáticas. Ello obedecía a una propuesta realizada por Ignacio de Hermosilla, uno de los secretarios de este instituto. ¿Se trataba de abrigar una esperanza ya casi vieja de los arquitectos de la Academia, que no habian sido capaces -o, más exactamente, que no se los habia permitido hasta entonces- de publicar su propio tratado, sin que interviniesen otras personas ajenas a la profesión? Es indudable que Silvestre Pérez se hacía eco, y así se le puede interpretar, de un sentimiento de disconformidad generalizado entre los profesores de arquitectura hacia este tratado entonces vigente en la Academia. 

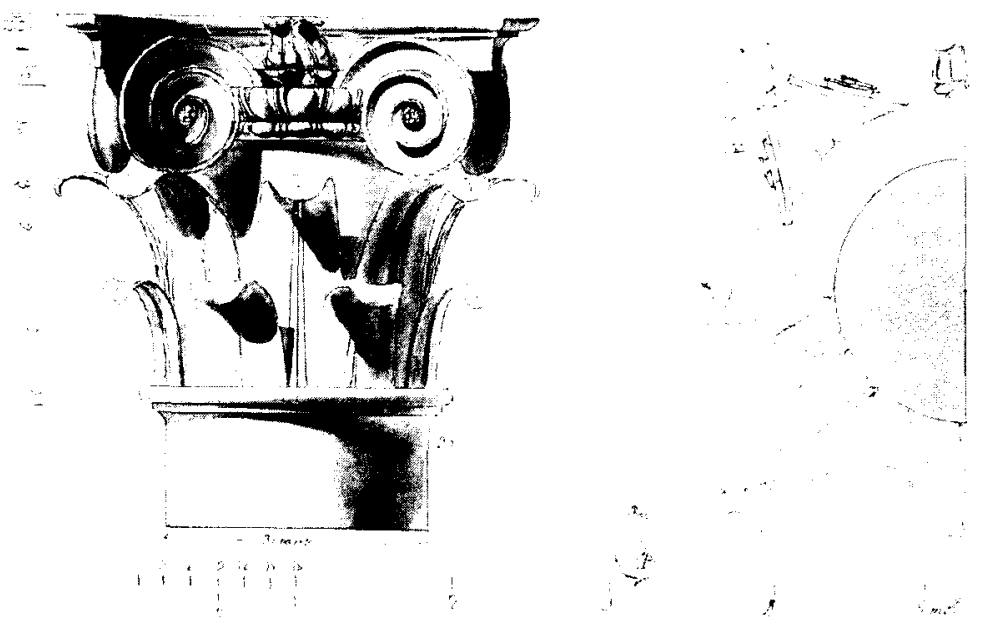

Lám. IX: Silvestre Pérez. Capitel dórico según Viñola. 1784.

\section{A MODO DE EPILOGO}

Durante la primera mitad del siglo XIX se confirmaron las mayoría de las disposiciones sobre la formación en las profesiones de la arquitectura propuestas en el reinado de Carlos III y primeros años del de Carlos IV, puliéndose algunas de ellas para lograr una mayor perfección. Asi, en 1803, 1805 y 1806, siendo el Marqués de Espeja viceprotector, se celebraron una serie de juntas extraordinarias para mejorar el plan de estudios general de la Academia. Partían de lo ya acordado en $1799{ }^{85}$. En la parceia dedicada a la arquitectura se comisionó en 1805 a López Aguado, Cuervo y Silvestre Pérez para que escribieran un informe, sustituyendo de esta forma a Betancout y Arnal, propuestos en $1803^{86}$. Lo presentaron el 23 de junio de $1805^{87}$. Incluian al mismo tiempo un índice temático de principios de arquitectura, que se deberían enseñar por los profesores en la

$\because \quad$ AASF: legs: $18-10 / 1$ y 18-36/1.

* Puntos acordados en las juntas del año 1803 sobre el plan de estudios en AASF: leg: : 1831/1. Sobre las reuniones de este año: AASF: legs. 18-10/1, 18-29/1 y 18-36/1. El informe del Marqués de la Espeja sobre el estado de los estudios, del 20 de marzo de 1803 en el leg.: 49-11/1.

Plan de estudios de arquiteciura, firmado por Juan Antonio Cuervo. López Aguado y Silvestre Pérez con fecha de 23 de junio de 1805 en AASF: leg.: 18/32-1. 
Academia. Pero el viceprotector les pidió una relación de tratados, que estuviera conforme con este programa.

En ese plan de estudios para la arquitectura de 1805, aprobado en 1806 , se indicaban algunos aspectos generales, que aquí tan sólo se insinuarán a continuación. Así, los discípulos de este arte debían seguir el aprendizaje del dibujo, como los pintores y escultores, hasta dibujar el modelo del yeso. Después estudiarian matemáticas con aplicación a la arquitectura y comenzarían la delineación; pero antes precisaban presentar certificados de haber adquirido conocimientos sobre gramática castellana. El origen de este arte se enseñaría siguiendo a Vitruvio. Por su tratado se explicarían en general y después en particular las partes que componen los tres ordenes griegos, el carácter de cada uno y su historia; pero distinguiendo lo esencial puro de ellos de lo superfluo. Seguidamente se aplicarían al estudio de Palladio, Scamozi y demás autores clásicos. También se dedicarían al aprendizaje de la historia de las bellas artes y de la jurisprudencia aplicada a ellas. La propuesta de Silvestre Pérez se confirmaba de esta forma.

Se mejoraron, además, algunos aspectos prácticos de la Comisión de arquitectura de la Academia madrileña. Así, en la junta particular del 17 de febrero de 1805 se dispuso que se retuvieran los planos reprobados de obras públicas proyectadas en sus censuras para impedir su realización. Quedaban en depósito en este centro, tal y como ya se había acordado en la junta ordinaria del 5 de diciembre de 1802 a propuesta de Pedro Arnal ${ }^{88}$. Pero, además, se pidieron ya en 1808 listas certificadas de los sujetos aprobados por las otras Academias, la de San Carlos de Valencia, San Luis de Zaragoza y de la Purísima Concepción de Valladolid, con distinción de clases para poder controlar las titulaciones de los autores de los proyectos llegados a la de San Fernando para su censura.

Las peculiares circunstancias de una España ensangrentada por la Guerra de la Independencia contra los franceses, cuyas ciudades habían sufrido los desastres constantes de la contienda, fueron las causas inductoras de la revisión en 1816 de las profesiones de la arquitectura. Pocos meses antes se habia depurado de la Academia a miembros colaboracionistas con José Bonaparte, el rey intruso, y entre ellos a Silvestre Pérez, quien se expatrió con los franceses ${ }^{89}$. Por real orden del 28 de agosto, firmada por Pedro Cevallos, Fernando VII (lám. X) estableció cuatro clases

Sobre la retención de los planos reprobados por la Comisión de arquitectura AASF: ieg 28-1/2

Sobre las purificaciones de los miembros de la Academia madrileña y algunos incidentes ocurridos durante la guerra: AASF: legs: : 4-8/1, 4-29/1 y 31-3/1 


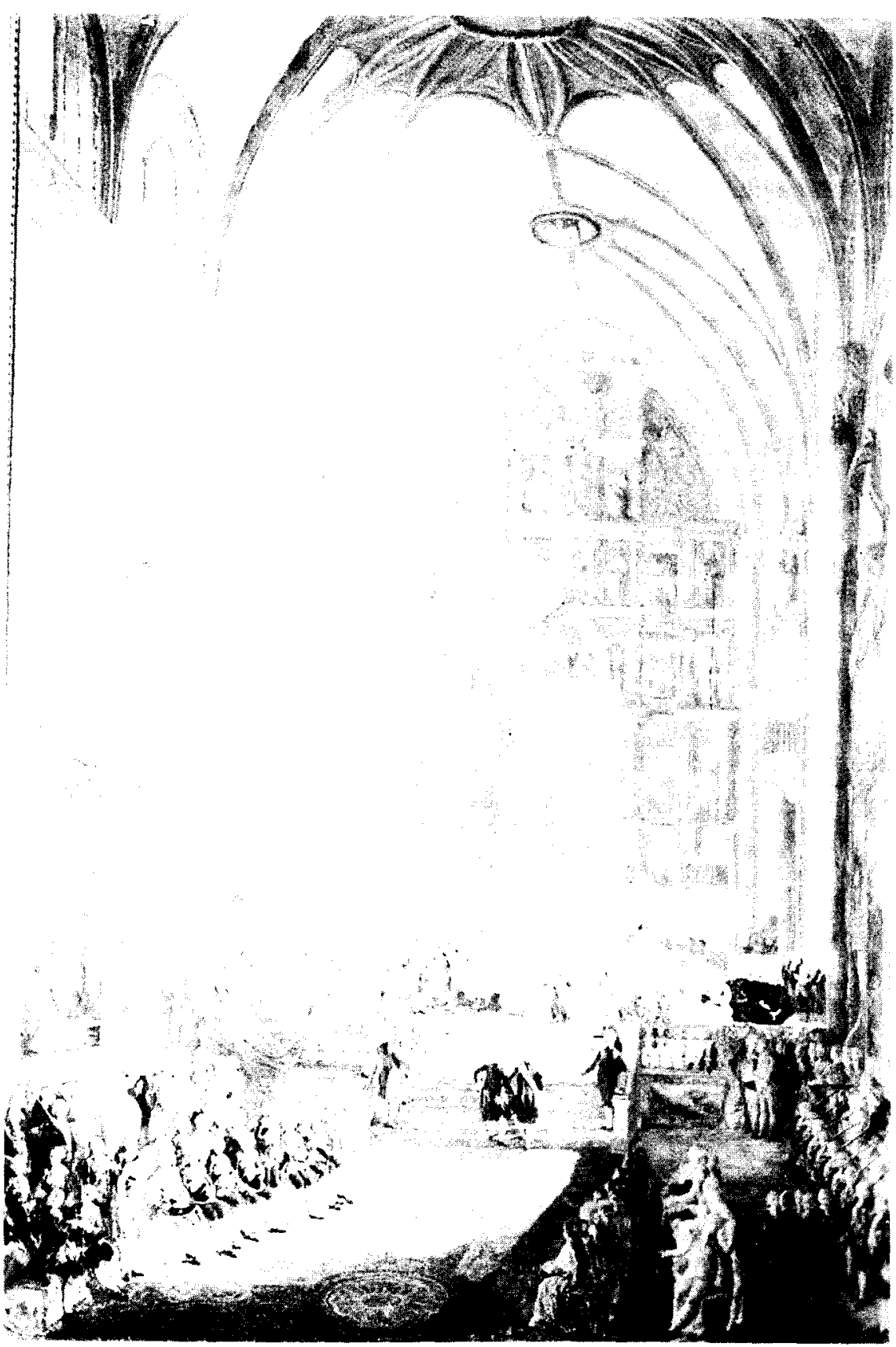

Lám. X: Paret: Jura de Fernando VII. Museo del Prado. 
de profesionales de la arquitectura: académicos de mérito o grado de incorporación a la Academia, arquitectos, maestros de obras y aparejadores facultativos ${ }^{90}$. Así, desaparecía el título de maestro arquitecto, creado en 1796, y se volvía al de arquitecto, al tiempo que se retornaba al de maestro de obras. Se institucionalizaba con un matiz ambiguo la denominación de aparejador facultativo, que era un premio a determinados sujetos, que por su avanzada edad $u$ otras razones poderosas no habian podido alcanzar la clase de maestro de obras.

Con posterioridad a la promulgación de esa real orden de 1816 se publicó una Ordenanza Artística, en la cual se indicaban las funciones de los distintos grados de profesionales de la arquitectura, su gobierno y requisitos, que debían concurrir para su aprobación. De esta forma los académicos de mérito gozaban de una serie de beneficios. Serían convocados y concurririan a todas las juntas públicas y generales con voz y voto, pudiéndoseles llamar para las ordinarias. Asistirían con cierta frecuencia a los estudios de la Academia, y estaban capacitados para sustituir a los profesores en sus ausencias. Sus facultades eran ilimitadas en todos los dominios de la Monarquía desde la invención y dirección del palacio o catedral más magnífica hasta el del más humilde edificio. Serían con preferencia arquitectos mayores de las ciudades, capitales, Santas Iglesias e intendencias; pero sus destinos deberían ser siempre conocidos por la Academia. De entre ellos se nombrarían a los directores de las Academias y Escuelas Subalternas del Reino. 